\title{
ArcheoSciences
}

Revue d'archéométrie

41-2 | 2017

Varia

\section{Sedimentological and malacological comparisons between the Upper Saalian and Upper Weichselian loess superimposed in the Nantois cliff (Brittany, France): Reconstruction of their environments south of the British Ice Sheet}

Comparaison sédimentologique et malacologique entre les loess weichseliens et saaliens superposés dans la falaise de Nantois (Bretagne, France): Reconstruction de leurs environnements au sud de la calotte glaciaire britannique

Guzel Danukalova, Jean-Pierre Lefort, Jean-Laurent Monnier, Eugenia Osipova, François Pustoc'h and Jean-Christophe Le Bannier

\section{(2) OpenEdition}

\section{Journals}

Electronic version

URL: https://journals.openedition.org/archeosciences/5001

DOI: 10.4000/archeosciences.5001

ISBN: 978-2-7535-7393-2

ISSN: 2104-3728

Publisher

Presses universitaires de Rennes

Printed version

Date of publication: 8 December 2017

Number of pages: $63-84$

ISBN: 978-2-7535-7391-8

ISSN: 1960-1360

\section{Electronic reference}

Guzel Danukalova, Jean-Pierre Lefort, Jean-Laurent Monnier, Eugenia Osipova, François Pustoc'h and Jean-Christophe Le Bannier, "Sedimentological and malacological comparisons between the Upper Saalian and Upper Weichselian loess superimposed in the Nantois cliff (Brittany, France):

Reconstruction of their environments south of the British Ice Sheet", ArcheoSciences [Online], 41-2 I 2017, Online since 08 December 2019, connection on 01 February 2022. URL: http:// 


\title{
Sedimentological and Malacological Comparisons between the Upper Saalian and Upper Weichselian Loess Superimposed in the Nantois Cliff (Brittany, France): Reconstruction of their Environments South of the British Ice Sheet
}

\author{
Comparaison sédimentologique et malacologique entre les loess weichseliens \\ et saaliens superposés dans la falaise de Nantois (Bretagne, France) : \\ reconstruction de leurs environnements au sud de la calotte glaciaire britannique
}

\author{
Guzel Danukalova $^{\mathrm{a}, \mathrm{c}}$, Jean-Pierre Lefort ${ }^{\mathrm{b}}$, Jean-Laurent MonnieR ${ }^{\mathrm{b}}$, \\ Eugenia Osırova ${ }^{a}$, François Pustoc' $\mathrm{H}^{\mathrm{b}}$ and Jean-Christophe Le Bannier ${ }^{\mathrm{b}}$
}

\begin{abstract}
The site of Nantois is located in Brittany (France), almost at the westernmost end of Europe. The outcrop consists of loam, loess and slope deposits, now continuously eroded by the sea. The layers containing fragments of rock and loam are completely decalcified. Only the loess of the lower and upper parts of the section corresponding to the Nantois (Middle Pleistocene) and Sables-d'Or-Les-Pins (Late Pleistocene) formations are well preserved and display mollusc shells. A detailed study of the sediment and of the fauna permitted to better characterize the two loess. The older loess is characterized by a large variety of species. The analysis of their distribution indicates for the first time the existence of three moderate climatic improvements during the sedimentation. The lower part of the younger loess is poor in mollusc shells which are either absent or only exist as single finds or detritus, above, the molluscs composition indicates cold and severe climatic conditions during the sedimentation and can be correlated with the last glacial stage MIS 2. According to geochronological data, the upper part of the Nantois Formation corresponds to the glacial stage MIS 6. The origin of the discrepancies observed in the evolutions of the two loess was probably not related with the small difference in their distances respect with the Weichselian and Saalian British ice sheets but to the very different durations of the Upper Saalian (60 ka) and Upper Weischelian $(7 \mathrm{ka}$ ) loess depositions. The absence of any significant warming episode during the Upper Weischelian and the existence of three climatic improvements during the Upper Saalian support the concept of sub-Milankovitch cycles which suggests that we cannot have any climatic change during a period shorter than $11 \mathrm{Ka}$.
\end{abstract}

Résumé : Le site de Nantois est situé en Bretagne (France), presque à l'extrémité la plus orientale de l'Europe. L'affleurement est constitué de limons, de loess et de dépôts de pente maintenant régulièrement érodés par la mer. Les niveaux contenant des fragments de roches et des limons sont totalement décalcifiés. Seuls les loess des parties inférieures et supérieures de la coupe et correspondant aux formations de Nantois (Pléistocène moyen) et des Sables-d'Or-Les-Pins (Pléistocène supérieur) sont bien préservés et contiennent des mollusques. Une étude détaillée des sédiments et de la faune associée à permis de mieux caractériser ces deux types de loess. Les loess les plus anciens sont caractérisés par une large variété d'espèces. L'analyse de leur distribution à permis, pour la première fois de mettre en évidence trois améliorations climatiques modérées pendant la sédimentation. La partie inférieure des loess les plus récents est pauvre en mollusques, qui sont soit absents ou n'existent qu'en un seul exemplaire ou sous forme de fragments. Au-dessus, la nature des mollusques indique l'existence de conditions climatiques froides et sévères

a Institute of Geology of the Ufimian Scientific Centre, Russian Academy of Sciences, K. Marx St., 16/2, 450077, UfA, Russia. (danukalova@ufaras. ru)(myrte@mail.ru)

${ }^{b}$ Université de Rennes 1, Campus de Beaulieu, Laboratoire d'Archéosciences (bat. 24-25), 74205 CS, 35042 RENNES cedex. France. (monnier@univrennes1.fr) (jeanpierre970@yahoo.fr)

${ }^{c}$ Kazan Federal University, Kremlyovskaya Str., 18, 420008, KAZAN, Russia. 
pendant la sédimentation. Elles peuvent être corrélées avec le dernier stade glaciaire MIS 2. Selon les données géochronologiques la partie supérieure de la formation de Nantois correspondrait au stade glaciaire MIS 6. L'origine des différences que l'on observe dans l'évolution des deux types de loess neetait probablement pas liée à la faible différence de leur distance par rapport aux calottes glaciaires britanniques lors du Saalien Supérieur (60 ka) et du Weischelien (7ka). L'absence d'amélioration climatique significative pendant le Weischelien supérieur et la présence de trois améliorations climatiques pendant le Saalien supérieur est en faveur du concept de cycles de type sub-Milankovitch selon lequel il n'y aurait pas d'améliorations climatiques possibles pendant une période inférieure à 11 kilo-années.

Keywords: stratigraphy, Quaternary, Nantois site, loess, molluscs, granulometry, palaeo-environment.

Mots clés: stratigraphie, Quaternaire, site de Nantois, loess, mollusques, granulométrie, paleoenvironement.

\section{INTRODUCTION}

The site of Nantois is located in northern Brittany $\left(48^{\circ} 35^{\prime} 50.57^{\prime \prime} \mathrm{N}\right.$ and $\left.2^{\circ} 31^{\prime} 51.46^{\prime \prime} \mathrm{W}\right)$. It is situated in the eastern part of Saint Brieuc Bay, in the Pléneuf-ValAndré area, almost at the westernmost end of Europe. The Nantois cliff is the place where the stratotype of the Nantois Formation was first defined (Loyer et al., 1995) (Figure 1). The Western part of this cliff is characterized by the superimposition of two loess formations of Saalian and Late Weichselian ages. This outcrop is important in the regional geology because it is the only place where the Saalian loess is not completely decalcified in Brittany. Out of this zone the loamy pre-Eemian sediments are very patchy, affected by pedogenesis, reworked and decalcified. They are always absent more to the West. The sampled outcrop, which was first studied by Monnier (1973), consists of loam, loess and soliflucted slope deposits which are actually continuously eroded by the sea. Loess and loam accumulations are better developed on the East-facing studied slope than on the northern side of the Pléneuf-Val-André hill (Laforge, 2012).

The Nantois site corresponds also with a Palaeolithic site (Monnier, 1986). It is considered to represent a hunting rest area since it evidences well-preserved cut up remnants. This place is one of the many Middle Palaeolithic sites discovered in the area. Well-developed fauna assemblages characterize some of these sites.

A rapid test with hydrochloric acid on various layers of the cliff has shown that the levels containing rock fragments and loam (soils) are completely decalcified. It is only in the well preserved lower and upper parts of the outcrop that the Nantois (Saalian) (section 1) and Sables-d'Or-Les-Pins (Late Weichselian) (section 2) Formations contain some mollusc shells (Figure 2). The main part of the palaeontological material was collected during the Russian-French scientific research cooperation developed between 2011 and 2015.

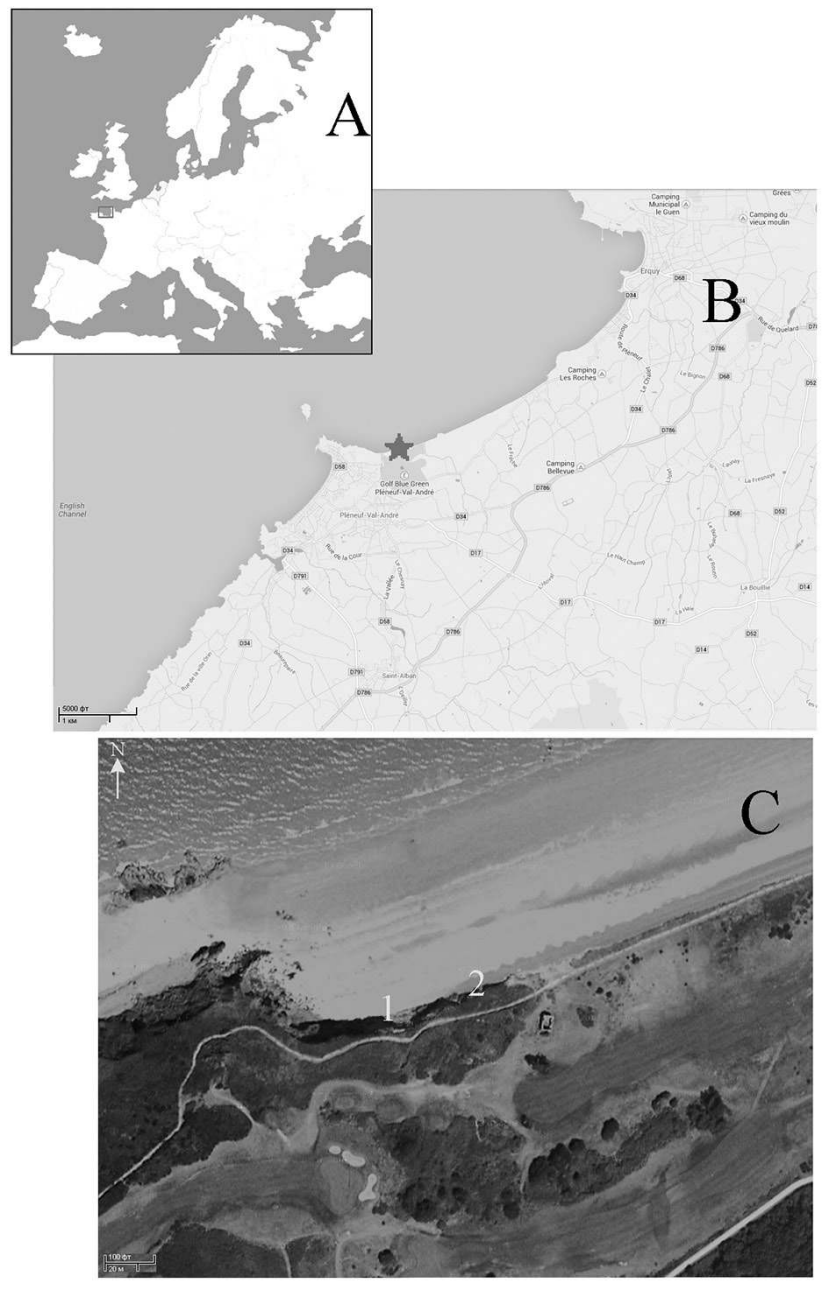

Figure 1: A. General situation of the Nantois site in Westernmost Europe. B and C. Location of Nantois in the framework of the Saint Brieuc Bay (A, B and C insets were copied from https:// maps.google.com/). 1 - Section 1 (Saalian loess); 2 - Section 2 (Weichselian loess).

Figure 1:A. Situation générale du site de Nantois en Europe de l'Ouest. B et C. Localisation du site de Nantois dans le cadre de la Baie de Saint-Brieuc (les vignettes A, B et $C$ sont tirées du site https:// maps.google.com/). 1-Section 1 : loess Saaliens; 2-Section 2 : loess Weichseliens. 
Figure 2: A: (See colour plate XVI) Panoramic view of the Nantois site showing the position of the two excavated sections. J.-L. Monnier and J.-P. Lefort give the scale. B: General view of the studied section (after Monnier, 1973). Figure 2: A: (Voir planche couleur XVI) Vue panoramique du site de Nantois montrant la position des deux sections. J.-L. Monnier et J.-P. Lefort donnent l'échelle. B: Vue générale

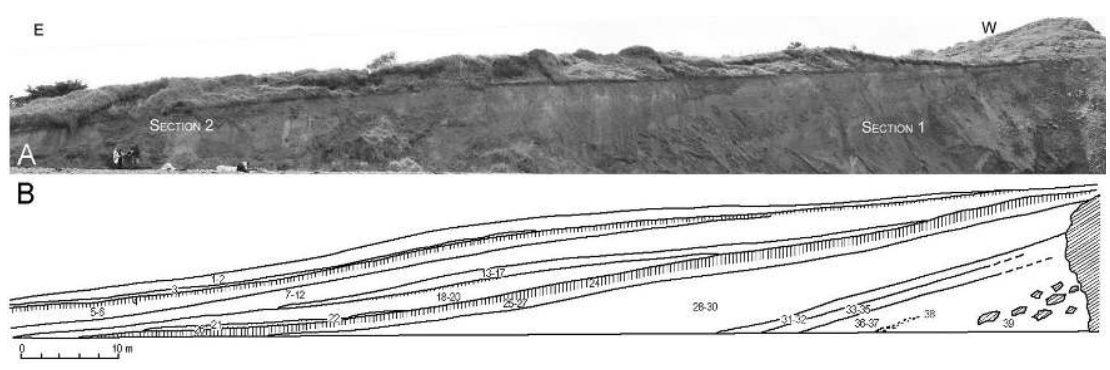
de la falaise (d'après Monnier, 1973).

We have been interested to compare these two formations thanks to the incorporated fauna and with the contribution of the physical characteristics of the sediment. The final purpose of this study was to check if the environmental conditions prevailing during the loess accumulations were identical or partly different since both types of sediments deposited during two successive cold periods.

\section{GENERAL BACKGROUND}

The general characteristics of the studied zone are briefly summarized below.

\section{General framework and regional setting}

Studies developed at the regional scale (Lefort et al., 2011; Danukalova et al., 2013) show that the Upper Pleistocene loess of Northern Brittany and Normandy result from the accumulation of a thin dust originating mainly in the central part of the Western English Channel and which were transported by strong winds blowing towards the south or the southeast (Bigot, 1986). The onshore loess contains heavy minerals and mainly garnets which can be used as markers (Lefort et al., 2011). The enrichment of the loess deposits in garnets can be compared with the concentration of the garnets found in the submarine placers associated with the now submerged Channel River (Lericollais, 2007), this comparison demonstrates the close relationship existing between the offshore and onshore mineralogical concentrations. Loess also contains coccoliths and foraminiferous (Estéoule et al., 1971) resulting from the frost chattering (Lautridou, 1971) of the offshore Cretaceous and Eocene outcrops. Loess deposits are now preferentially coating the north or northwest facing basement cliffs of the Northern shore of the Brittany Peninsula (Lefort et al., 2013).

\section{General stratigraphy of the outcrop}

The general stratigraphy of the Nantois cliff will not be described again. We send back the reader to a former paper where the main features of this cliff have been previously described (Loyer et al., 1995). In this paper we will only describe the stratigraphy of the two sections we studied.

\section{Geochronological background}

\section{Dating evidences}

Clear stratigraphic similarities observed between the Nantois cliff and the nearby sites of Piégu and Les Vallées, where radiometric datings have been carried out (Bahain et al., 2012), confirm the chronostratigraphic scheme previously suggested on the basis of field observations and major stratigraphic landmarks such as paleosols, palaeo-beaches and dunes, loamy facies etc. The regional Pleistocene stratigraphic scheme established during a period of forty years is, thus, fully confirmed and can be now incorporated with the geochronological data (Monnier, 2006; Laforge, 2012). In summary, the "Old loess" of Nantois site which is lying under a soliflucted layer represents the bedrock of a paleosol which can be correlated with the Eemian and rest above a sandy layer which is also present at Les Vallée site. At its top a Palaeolithic layer can be recognized (Huet, 2011). Because the archaeological layer is dated at about $165 \mathrm{Ka}$ by ESR-U/ Th (Bahain et al., 2012), the age of the "old loess" of Nantois can be estimated as ranging between $170 \mathrm{Ka}$ and $130 \mathrm{Ka}$.

The "Younger loess" is clearly resting above the Eemian paleosol and above the characteristic deposits of La HauteVille and Port-Morvan formations. The direct radiometric dating made by OSL technic (Loyer et al., 1995) provided an age of $18 \mathrm{Ka} \pm 2.5$. Other OSL datings have been made on the same levels in the nearby site à Sables-d'Or-Les-Pins (Folz, 2000). The ages obtained on these equivalent layers are close to $20 \mathrm{Ka}(21.9 \pm 1.9$ and $21.4 \pm 1.9)$. These results are not very different from those obtained by Manfred 
Frechen (Van Vliet et al., 1997) who evidenced a very rapid loess deposition reaching $1,5 \mathrm{~m}$ for 1000 years!

\section{MIS equivalences and correlations with the Global Quaternary scales}

The equivalences which will be used further in this paper must be first defined for a better clarity. It is now estimated that the Formation of Nantois ranges between MIS 6 and MIS 9 (and probably also MIS 10) that is to say approximately between 330 (or 350?) and $127 \mathrm{ka}$. The formation of La Haute Ville can be correlated with MIS 5 which ranges between 127 and $75 \mathrm{ka}$. The formation of Port-Morvan spreads between MIS 4 and the beginning of MIS 3, between 75 and $40 \mathrm{ka}$. The formation of Sables-d'Or-les-Pins developed between the second half of MIS 3 and MIS 2, between 40 and $15 \mathrm{ka}$ (Monnier, 1973; Monnier and Bigot, 1987; Bigot, 1986; Loyer et al., 1995; Monnier et al., 2011; Bahain et al., 2012). Taking account of all these data correlations between the Middle and Upper Pleistocene subdivisions of Northern Brittany with other units of Western Europe is proposed in Table 1.

\section{Malacological background}

Some mollusc shells have been previously discovered in the Nantois site, but were never described completely in any journal. The first informations regarding this site were given by Mazeres (1938), Beigbeder (1964) and Monnier (1973). Monnier took individual samples from Nantois which were studied by Puisségur for the mollusc species. They are listed in his PhD thesis (Monnier, 1973). Afterwards, this cliff only attracted the attention of sedimentologists (Monnier $e t$ al., 2011; Laforge, 2012). It was also one of the selected sites used to show the Pleistocene stratigraphy to students. In 2008 the Nantois cliff was shown to the participants of the INQUA SEQS field excursion in relationship with the meeting held in Rennes (Excursion Guidebook, 2008). In 2011-2015 the authors described and studied again this section.

\section{Materials ANd methods}

\section{Description on the field}

The colors of the Munsell Soil Color Chart have been used to describe the natural sediment before drying.

For the Nantois loess, colors vary between yellowish-brown and brownish-yellow (10 YR 5/4, 10 YR 5/5, 10 YR 6/6) but, at the base of the profile, the colors are darker (dark yellowishbrown $=10$ YR 3/4, 10 YR 4/4, 10 YR 4.5/6).
The colors of the Sables-d'Or-les-Pins loess are not very different. The main colors also vary between yellowish-brown and brownish-yellow but at the top of the profile the colors are darker (dark yellowish-brown = 10 YR 4.5/6, 10 YR 4.5/4, $10 \mathrm{YR} 4 / 6)$. It is a usual phenomenon in the post-glacial soils because of the clay illuviation and the oxidation.

\section{Procedure used in the malacological study}

The work on the molluscs of the Nantois section started in 2011 in the western part of the cliff where Late Middle Pleistocene loess deposits were known (section 1). A new section (section 2) was investigated in the eastern part of the same cliff in 2012 and 2014 . We mainly concentrated on the loess layers.

The sediments of sections 1 and 2 were sampled at $10 \mathrm{~cm}$ intervals; each sample represented a mass of approximately $2,5 \mathrm{~kg}$ or a volume of one cubic decimeter. In total 79 samples were examined. The thickness of the sampled Nantois loess was of $490 \mathrm{~cm}$ (49 samples); the thickness of the Sables-d'Or-les-Pins loess was of $300 \mathrm{~cm}$ (30 samples) (Figures 3 and 4).

The methodology described by Sümegi and Krolopp (2002) was followed, with the single difference of a closer spacing for sampling.

After their collection on the field, the samples were numbered and placed in plastic bags. In the laboratory, they were placed on plates and covered by water. After soaking overnight, they were washed through sieves of $0,5 \mathrm{~mm}$ and then air-dried. After drying, they were stored in plastic containers and labeled. The visual inspection of the samples revealed unbroken mollusc shells, big fragments of shells and fine impossible to describe detritus. Because the number of mollusc shells is important in the interpretation of the Upper Pleistocene terrestrial deposits, the shells were examined and extracted individually. The quantity of extracted shells was very different depending on the investigated level (See Tables 2 and 3). Their abundance is given according to the method of Ložek (1964). The number of complete shells plus the number of apices or apertures which were considered as equivalent to one shell when taken together were counted. Then, the resulting amount of species, matched on the fragments, was added to the unbroken specimen. Additionally we counted undetermined shell fragments in order to get quantitative information on the environmental characteristics. The percentage of species in the samples was not counted, because this method needs more than 200 specimens of shells in each sample (White et al., 2008) to be valid.

Afterwards, each sample was calibrated according to the species structure with the help of brushes and with a 


\begin{tabular}{|c|c|c|c|c|c|c|c|}
\hline \multicolumn{3}{|c|}{$\begin{array}{l}\text { Global Quaternary scheme Gibbard \& Cohen } \\
\qquad(2008)\end{array}$} & \multirow{2}{*}{\multicolumn{2}{|c|}{$\begin{array}{c}\text { West European stratigraphic divi- } \\
\text { sions* (The Netherlands) / Ma } \\
\text { Turner (1998), Zagwijn (1996), } \\
\text { Busschers et al. (2008) }\end{array}$}} & \multirow{2}{*}{$\begin{array}{l}\text { Sibrava, Bowen } \\
\text { \& Richmond } \\
1986\end{array}$} & \multirow{2}{*}{$\begin{array}{l}\text { Northern Brit- } \\
\text { tany Monnier } \\
\text { et al. }(1997)\end{array}$} & \multirow{2}{*}{$\begin{array}{l}\text { Marine Isotope } \\
\text { Stages }\end{array}$} \\
\hline System & Series & Subseries, stages & & & & & \\
\hline \multirow{15}{*}{ 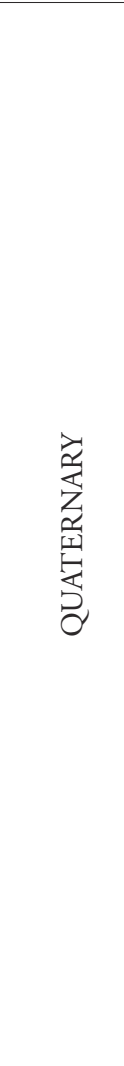 } & \multirow{3}{*}{ HOLOCENE } & UPPER & \multicolumn{2}{|c|}{ Upper } & \multirow{3}{*}{ Holocene } & \multirow{3}{*}{ Holocene } & \multirow{3}{*}{1} \\
\hline & & MIDDLE & \multicolumn{2}{|c|}{ Middle } & & & \\
\hline & & LOWER & \multicolumn{2}{|c|}{ Lower 0.01} & & & \\
\hline & \multirow{12}{*}{ 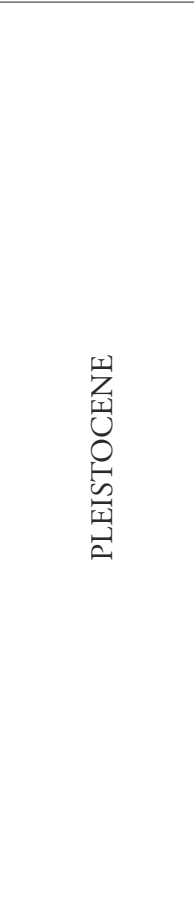 } & \multirow{5}{*}{ UPPER } & \multicolumn{2}{|c|}{ Upper Weichselian } & \multirow{4}{*}{ Weichselian } & $\begin{array}{l}\text { Sables-d'Or-les- } \\
\text { Pins Formation }\end{array}$ & 2 \\
\hline & & & Middl & eichselian & & \multirow{2}{*}{$\begin{array}{l}\text { Port Morvan } \\
\text { Formation }\end{array}$} & 3 \\
\hline & & & \multirow{2}{*}{\multicolumn{2}{|c|}{ Lower Weichselian }} & & & 4 \\
\hline & & & & & & \multirow{2}{*}{$\begin{array}{l}\text { La Haute-Ville } \\
\text { Formation }\end{array}$} & $5 a-d$ \\
\hline & & & \multicolumn{2}{|c|}{ Eemian 0.127} & Eemian 0.132 & & $5 e$ \\
\hline & & \multirow{7}{*}{ 菂 } & \multirow{5}{*}{ Saalian } & $\begin{array}{l}\text { Drenthe glacia- } \\
\text { tion } \\
\text { Cold Interval } \\
\text { with permafrost }\end{array}$ & Warthe 0.198 & \multirow{6}{*}{$\begin{array}{l}\text { Nantois } \\
\text { Formation }\end{array}$} & 6 \\
\hline & & & & $\begin{array}{l}\text { Bantega inters- } \\
\text { tadial }\end{array}$ & $\begin{array}{l}\text { Drenthe- } \\
\text { Warthe } 0.252\end{array}$ & & 7 \\
\hline & & & & Cold Interval & Drenthe & & 8 \\
\hline & & & & $\begin{array}{l}\text { Hoogeveen } \\
\text { Interstadial }\end{array}$ & Domnitz 0.338 & & 9 \\
\hline & & & & $\begin{array}{c}\text { Cold interval } \\
\text { with permafrost }\end{array}$ & Fuhne 0.352 & & 10 \\
\hline & & & Holsteinian & terglacial 0.427 & $\begin{array}{l}\text { Holsteinian } \\
0.428\end{array}$ & & 11 \\
\hline & & & & rian & Elsterian 0.480 & & 12 \\
\hline
\end{tabular}

Table 1: Comparison between the Middle to Upper Pleistocene stratigraphic units previously recognized in the Northern part of Brittany with known successions of Western Europe.

*West European stratigraphical divisions for the upper Middle Pleistocene are given according to Busschers et al. (2008) and Turner (1998), Late Pleistocene divisions according to Zagwijn (1996).

Tableau 1: Comparaison entre la stratigraphie des unités reconnues au nord de la Bretagne avec des unités connues en Europe de l'Ouest.

MBS 10 binocular microscope with different amplification $(\times 4-\times 10)$.

The determination of the species was done according to the detailed works of Likharev and Rammelmeier (1952), Shileyko (1978, 1984), Shileyko and Likharev (1986), and Kerney and Cameron (1999). The classification was given according to Falkner et al. (2002).

The published data about the modern mollusc species and their ecological preferences for air temperature, humidity, and vegetation cover were considered (Germain, 1930; Likharev \& Rammelmeier, 1952; Adam, 1960; Zilch and Jaeckel, 1962; Ložek, 1964; Puisségur, 1976; Kerney et al., 1983; Shileyko, 1978, 1984; Kerney \& Cameron, 1999; Willis et al., 2000; Sümegi \& Krolopp, 2002; Sysoev \& Shileyko, 2009; Animal base, n.d.).
The palaeontological collections are kept at the Institute of Geology (Ufa Scientific Centre RAS, Ufa).

Shells of the molluscs were photographed in the laboratory of Archéosciences of the University Rennes 1 (Rennes, France) on a stereomicroscope Leica M205C with a camera Leica DFC295.

\section{Procedure used in the physical study of the sediments}

The granulometry has been made with the help of a Laser particle size analyzer (Cilas 1180L) after elimination of the calcium carbonate by hydrochloric acid. This first step is necessary in order to homogenize the results of the different series of samples. It is known that after deposition, 


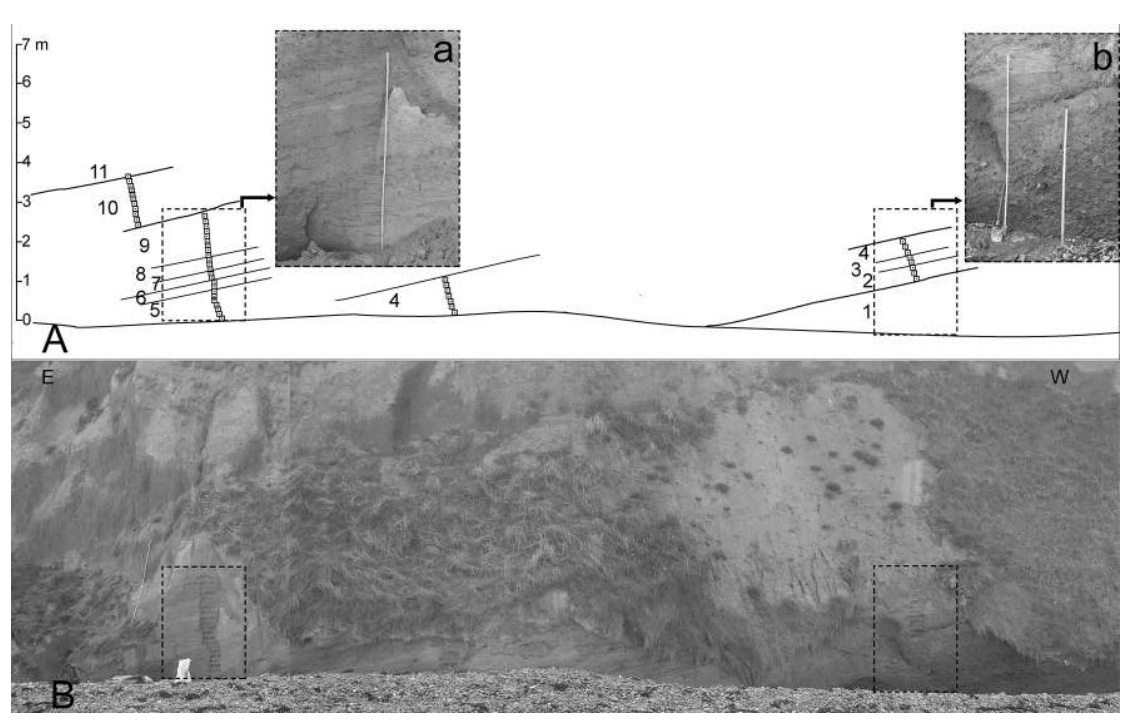

Figure 3: (See colour plate XVI) Photograph (B) and schematic organization (A) of the Western part (late Middle Pleistocene) of the Nantois site. Arabic numbers correspond with layers recognized in section 1 . The little squares indicate the location of the samples (numbers are given in the text). The photographs shown in a dashed rectangle indicate: $\mathrm{a}$ - the lower and $\mathrm{b}$ - the middle parts of the Section 1 .

Figure 3: (Voir planche couleur XVI) Photographie (B) et organisation schématique (A) de la partie orientale (Pléistocène Moyen terminal) du site de Nantois. Les chiffres arabes correspondent aux niveaux reconnus dans la coupe 1. Les carrés indiquent la localisation des échantillons (les numéros sont donnés dans le texte). Les photographies présentées dans le rectangle hachuré indiquent : a : la partie inférieure et $b$ : la partie moyenne de la section 1.

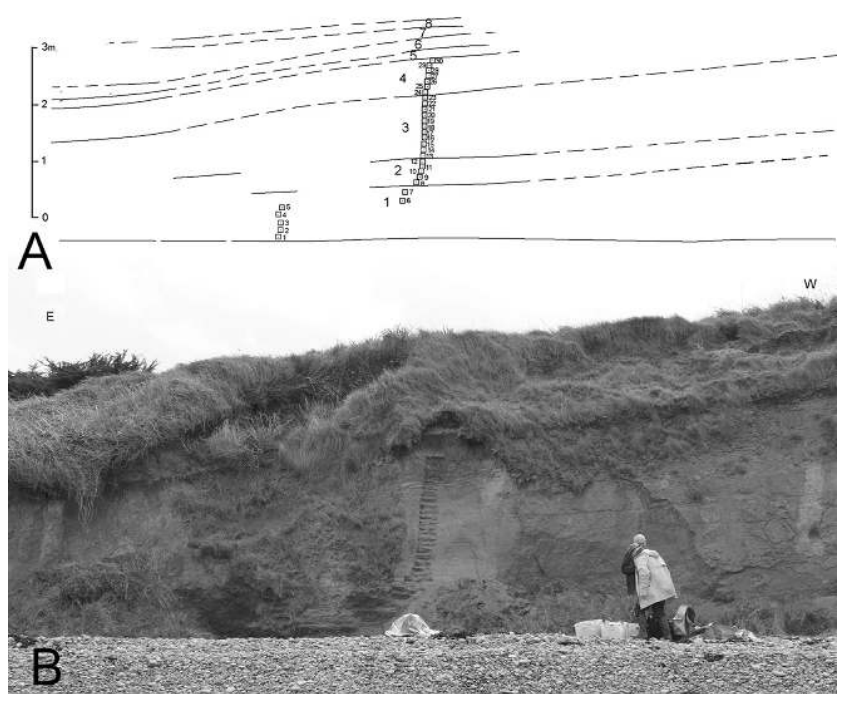

Figure 4: (See colour plate XVII) Photograph (B) and schematic organization (A) of the eastern part (late Late Pleistocene) of the Nantois site. Large Arabic numbers correspond with the layers recognized in section 2. Small Arabic numbers located close to the little squares correspond to the sampling references. J.-L. Monnier and J.-P. Lefort give the scale.

Figure 4: (Voir planche couleur XVII) Photographie (B) et organisation schématique (A) de la partie orientale (Pléistocène Supérieur terminal) du site de Nantois. Les grands chiffres arabes correspondent aux niveaux reconnus dans la coupe 2. Les petits chiffres arabes situés prés des petits figurés carrés correspondent aux références d'échantillonnage. J.-L. Monnier et J.-P. Lefort donnent l'échelle.

the calcium carbonate contained in the loess almost always moves under the effect of different pedological processes and precipitated as "conglomerate" and calcareous concretions ("loess doll"). This elimination of $\mathrm{CaCO}_{3}$ is also necessary to avoid clay flocculation. Calcium carbonate has been measured by X Fluorescence. Granulometry and Carbonates analysis have been made on the loess samples selected for malacology.

\section{RESULTS OF THE RECENT INVESTIGATIONS}

\section{Stratigraphy}

The description of the late Middle (section 1) and Late Pleistocene (section 2) deposits investigated in this study is given below. The two sections are separated by a horizontal distance of $45 \mathrm{~m}$ (Figure 2).

\section{Section 1: Late Middle Pleistocene (Figure 3)}

1. Brown and black angular fragments of Palaeozoic rocks analog to slope deposits (soliflucted?) with sand layer $(0.35 \mathrm{~m}$ thick) and lens of gravel colored in black by Fe and Mn oxides (total thickness: $6.0 \mathrm{~m}$ ). 2. Alternation of poorly rounded rock fragments and yellowish grey loess-like loam with possible traces of pedogenesis (thickness: $0.3 \mathrm{~m}$ ). 3 . Dark yellowish brown loam (soil?) (thickness: $0.2 \mathrm{~m}$ ). 4 . Dark yellowish brown loess with rock fragments in the upper part of the layer (thickness: $1.0 \mathrm{~m}$ ). 5. Brownish yellow loess with very thin layers showing a different color (thickness: $0.7 \mathrm{~m}$ ). 6. Brownish yellow loess with rock fragments (thickness: $0.2 \mathrm{~m}$ ). 7. Yellowish brown loess (thickness: $0.2 \mathrm{~m}$ ). 8 . Yellowish brown loam (soil) (thickness: $0.3 \mathrm{~m}$ ). 9. Yellowish brown loess (thickness is $0.9 \mathrm{~m}$ ). 10. Yellowish brown loess with rock fragments (thickness: $1.1 \mathrm{~m}$ ). 11. Reddish loam 
with fragments of rocks (thickness: $0.4 \mathrm{~m}$ ). The total thickness of the deposits including the loess is of $15.3 \mathrm{~m}$.

Layers 1 to 10 correspond to the Nantois Formation (Middle Pleistocene).

\section{Section 2: Upper Pleistocene and Holocene (Figures 4 and 5)}

1) Alternation of yellowish grey loess-like loam and poorly rounded rock fragments (thickness: $1.0 \mathrm{~m}$ ). 2) Alternation of very thin layers of a yellowish grey loess-like loam, sand and angular rock fragments. Cryoturbations were not observed in our sections but are known in the same horizon a little bit further West (Loyer et al., 1995). The size of the rock fragments and their quantity decreases towards the top of the layer (thickness: $0.5 \mathrm{~m}$ ). 3) Light yellowish grey porous calcareous loess with calcareous rhizomorph concretions. The upper part $(0.3 \mathrm{~m})$ of the layer is decalcified (thickness: $1.2 \mathrm{~m}) .4$ ) Reddish brown clay-rich loam alternating with loess-like loam influenced by soil processes; it corresponds to what is called "striped illuviation" at the base of a brown illuviated forested soil (thickness: $0.6 \mathrm{~m}$ ). 5) Light grey dust-like calcareous sandy loam (horizon $\mathrm{A}_{2}$ ). Traces of weathering (thickness: 0.2 to $0.3 \mathrm{~m}) .6$ ) Dark grey sandy loam (horizons A1/A2 and $\mathrm{Bt}$ )

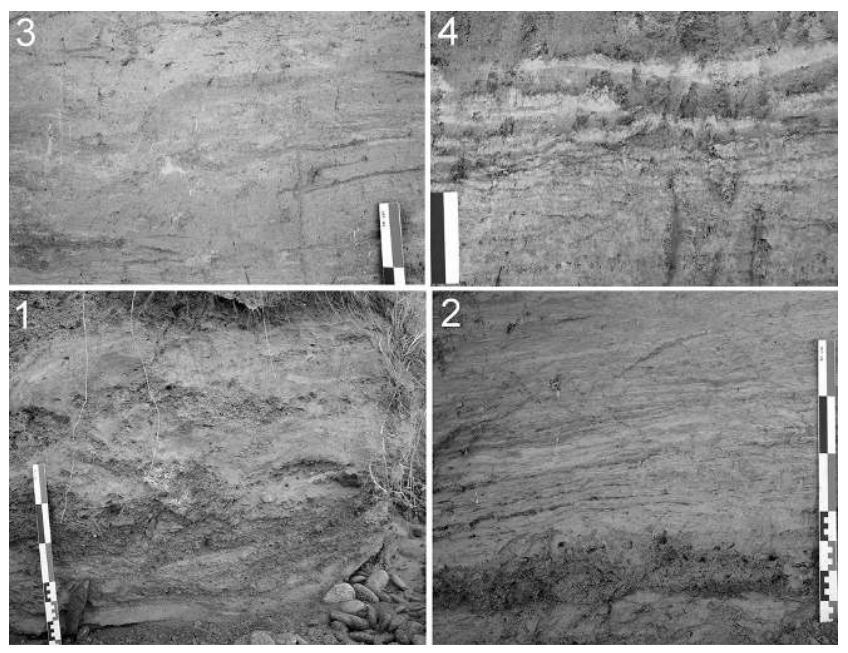

Figure 5: (See colour plate XVII) Nantois site. Deposits of the Sables-d'Or-les-Pins Formation (late Late Pleistocene), Section 2: 1 - slope (soliflucted?) and aeolian deposits observed in layer 1 ; 2 - aeolian and slope (ravine) deposits observed in layer 2; 3 aeolian deposits typical of layer 3; 4 - aeolian deposits affected by soil processes in layer 4 . Scale: $10 \mathrm{~cm}$.

Figure 5 : (Voir planche couleur XVII) Site de Nantois. Dépôts de la formation de Sables-d'Or-les-Pins (fin du Pléistocène terminal), Section 2 : 1-Dépôts de pente (soliflués?) et dépôts éoliens observés dans la couche 1; 2-Dépôts de pente (ravinement) et éoliens observés dans la couche 2; 3-Dépôts éoliens typiques de la couche 3; 4-Dépôts éoliens affectés par la pédogenèse dans la couche 4 . Échelle: $10 \mathrm{~cm}$. (thickness: $0.3 \mathrm{~m}$ ). 7) Light yellowish grey aeolian sand (thickness: $0,2 \mathrm{~m}$ ). 8) Dark grey sandy loam (modern soil) (thickness: $0,2 \mathrm{~m}$ ). The total thickness of the deposits of Section 2 is $4.3 \mathrm{~m}$.

Layers 1 to 5 correspond to Sables-d'Or-les-Pins Formation (upper part of the Upper Pleistocene). Layers 6 to 8 are Holocene in age.

\section{Sedimentological study}

The analysis of the granulometric curves of Nantois and Sables-d'Or-les-Pins loess (Figures 6 and 7) generated the following results:

- The median Md is, by enlarge, a little bit higher for the Sables-d'Or-les-Pins loess but the standard deviation is a little bit lower, which suggests that they are in general a little bit coarser.

- On the stratigraphic diagrams showing the Nantois and Sables-d'Or-les-Pins profiles, the Nantois profile shows thinner sediments at the base and coarser deposits at the level of samples 8 and 9. The rest of the profile is irregular which may result from some trickling effects.

- The index sorting $\mathrm{Hq}$ is slightly higher for the Nantois loess but with a lower standard deviation, showing that they are less well sorted.

- The stratigraphic diagrams show an irregular sorting for the Nantois loess (more irregular than in the Sables-d'Orles-Pins loess), save at the level of two anomalies (samples 8 and 28) where the sorting is better and even better expressed towards the bottom of the profile.

- The Asq index is slighly lower for the Nantois loess. The curves are, by enlarge more symmetric but always positive which show a better sorting of the coarser particles.

- On the stratigraphic diagram the symmetry is good towards the bottom of the profile but decrease rapidly between samples 2 and 10. Then it is variable towards the top. The Sables-d'Or-les-Pins loess displays a random asymmetry and in general a very asymmetric trend.

-0.2 micron clay diagrams:

Nantois loess show a higher rate at the bottom of the profile (samples 1 and 2) which could be related with some trickling of the thin particles originating in the underlying eroded soil.

Sables-d'Or-les-Pins loess display rapidly increasing values towards the top of the profile (samples 25 to 30 ) which is probably related with the post glacial pedogenesis.

-2 microns clay diagram:

Nantois loess show a higher rate at the bottom of the profile (samples 1 and 2) but an anomaly of unknown origin towards the bottom (sample 26).

Sables-d'Or-les-Pins loess does not display any particular trend. 
-6 microns clay diagram:

Nantois loess show a high rate at the bottom of the profile but then decreases, becomes irregular and looks lower save for sample 26.

Sables-d'Or-les-Pins loess display variable rates between 7 and 14\%, some horizons are richer than others in par- ticles thinner than 6 microns. There is no enrichment at the top.

$$
\text { - Carbonates: }
$$

Nantois loess is poorly carbonated in the lower part. Then it increases with the concretions level (migrated calcium level). On top it is decalcified under the Eemian soil.

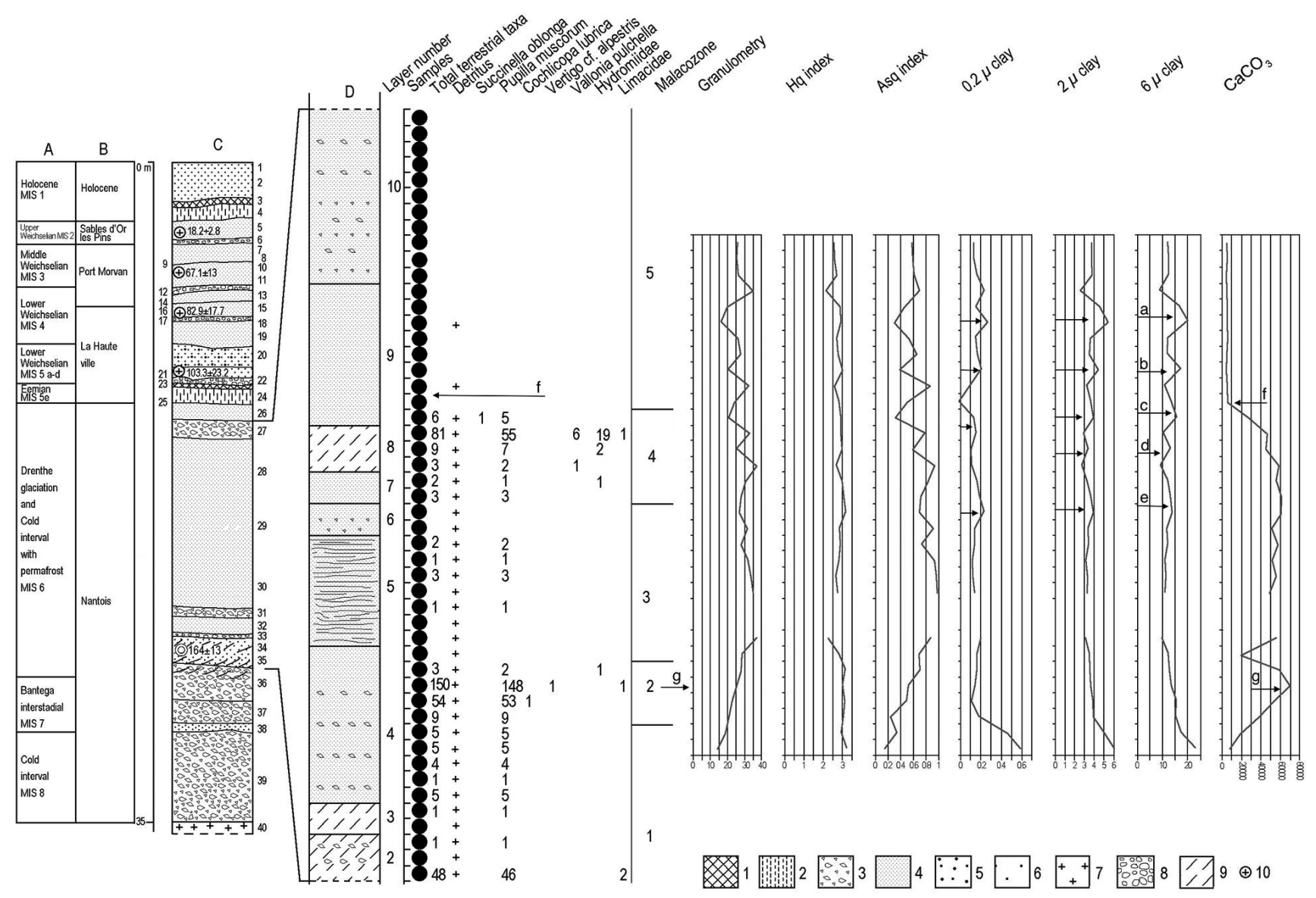

Figure 6: Frequency of terrestrial molluscs, granulometry and calcimetry curves measured in the deposits of the Nantois Formation (Middle Pleistocene) of the Nantois site and possible attribution to the regional (A) and general (B) stratigraphical schemes used in this paper. C Section: Nantois loess section: paleosol sequence according to Monnier (1973) and Laforge (2012): small Arabic numbers indicate the numbering of the lithological units. D Section: investigated loess interval (Saalian), molluscs occurences, granulometry and calcimetry data. The given values represent the numbers of total land snails found in a sample. The symbol + indicates the presence of shells detritus in a sample. Lithologic symbols: 1: soil (A horizon); 2: soil (B horizon); 3: colluvium (angular rock fragments) (=head); 4: loess or loess-like loam; 5: loamy sand; 6: sand; 7: basement; 8: pebbles; 9: loam; 10: OSL ages. Measured physical and chemical parameters: Hq: sorting; Asq: asymmetry; $0.2 \mu$ clay: rate of $0.2 \mu$ clay; $2 \mu$ clay: rate of $2 \mu$ clay; $6 \mu$ clay: rate of $6 \mu$ clay; $\mathrm{CaCO}_{3}$ : carbonate of calcium rate. Symbols given in column 1: Cross in a circle - TL dates (Ka) after Loyer et al., 1995, double circle - ESR / U-Th data after Bahain et al., 2012. Figure 6: (Voir planche couleur) Fréquence des mollusques terrestres, granulométrie et calcimétrie mesurées dans la Formation de Nantois (Pléistocène moyen) du site de Nantois et correlation possible avec le schéma stratigraphique régional (A) et général (B) utilisés dans cette publication. Coupe $C$ : Loess de la section de Nantois : séquence de paléosol d'aprés Monnier (1973) et Laforge (2012) : les petits chiffres arabes indiquent la numérotation des unités lithologiques. Coupe D : section de loess étudiés (Saalien), présence de mollusques, données granulométriques et calcimétrie. Les valeurs données représentent le nombre total de gastéropodes continentaux trouvés par échantillon. Le symbole + indique la présence de fragments coquilliers par échantillon. Symboles lithologiques : $1: \operatorname{sol}$ (horizon A); $2: \operatorname{sol}$ (horizon B); $3:$ colluvion (fragments anguleux de roche) (=head); $4:$ loess ou limon loessique; 5 : sables limoneux; $6:$ sable; 7 : socle; 8 :galets; 9 : limon; 10 : age OSL; Mesure des paramètres physiques et chimiques : Hq : tri; Asq : asymétrie; $0.2 \mu$ : taux d'argiles à $0,2 \mu ; 2 \mu$ : taux d'argiles à $2 \mu ; 6 \mu$ : taux d'argiles à $6 \mu$; CaCO3 : concentration en carbonate de calcium. Symboles : croix dans un cercle : age TL (Ka) d'après Loyer et al., 1995, double cercle : age ESR/U-Th d'aprés Bahain et al., 2012. 
The Sables-d'Or-les-Pins is moderately carbonated in its lower part and then clearly enriched in calcium and at last decalcified under the post-glacial soil.

\section{Malacological study}

\section{Molluscan distribution according to the depth respect to the surface}

In sections one and two the analysis of the distribution of the molluscs according to the depth respect with the surface shows that the mollusc shells are irregularly located in the loess (Tables 2 and 3).

The upper part of Section 1 (Nantois Formation), layers 10 and partly 9 ( $1.2 \mathrm{~m}$ thick) does not contain any shell. These deposits were affected by the formation of the brown soil (Eemian) which deposited above the "old loess". This part of the section is slightly reddish because of the $\mathrm{Fe}$ and $\mathrm{Al}$ oxides which were washed out from the overlying soil. The largest amount of shells is concentrated at the lower part of the studied section (layer 2), between 1.20 and $1.40 \mathrm{~m}$ depth (layer 4 ) and between 2.80 and $3.00 \mathrm{~m}$ depth (layer 8 ). It is likely that these sedimentary zones deposited in slightly better climatic conditions. The other zones of the investigated section contain fewer mollusc shells.

The upper part of the Section 2 (Sables-d'Or-les-Pins Formation) (layer 4 of $1.0 \mathrm{~m}$ thick) does not contain any shell. These deposits were affected by the formation of the overlying soil (Holocene). The biggest amount of shells is concentrated at the depth of 0.80-1.60 m (layer 2 and partly layer 3). The lower part (layer 1) of the investigated section contains smaller amounts of mollusc shells.
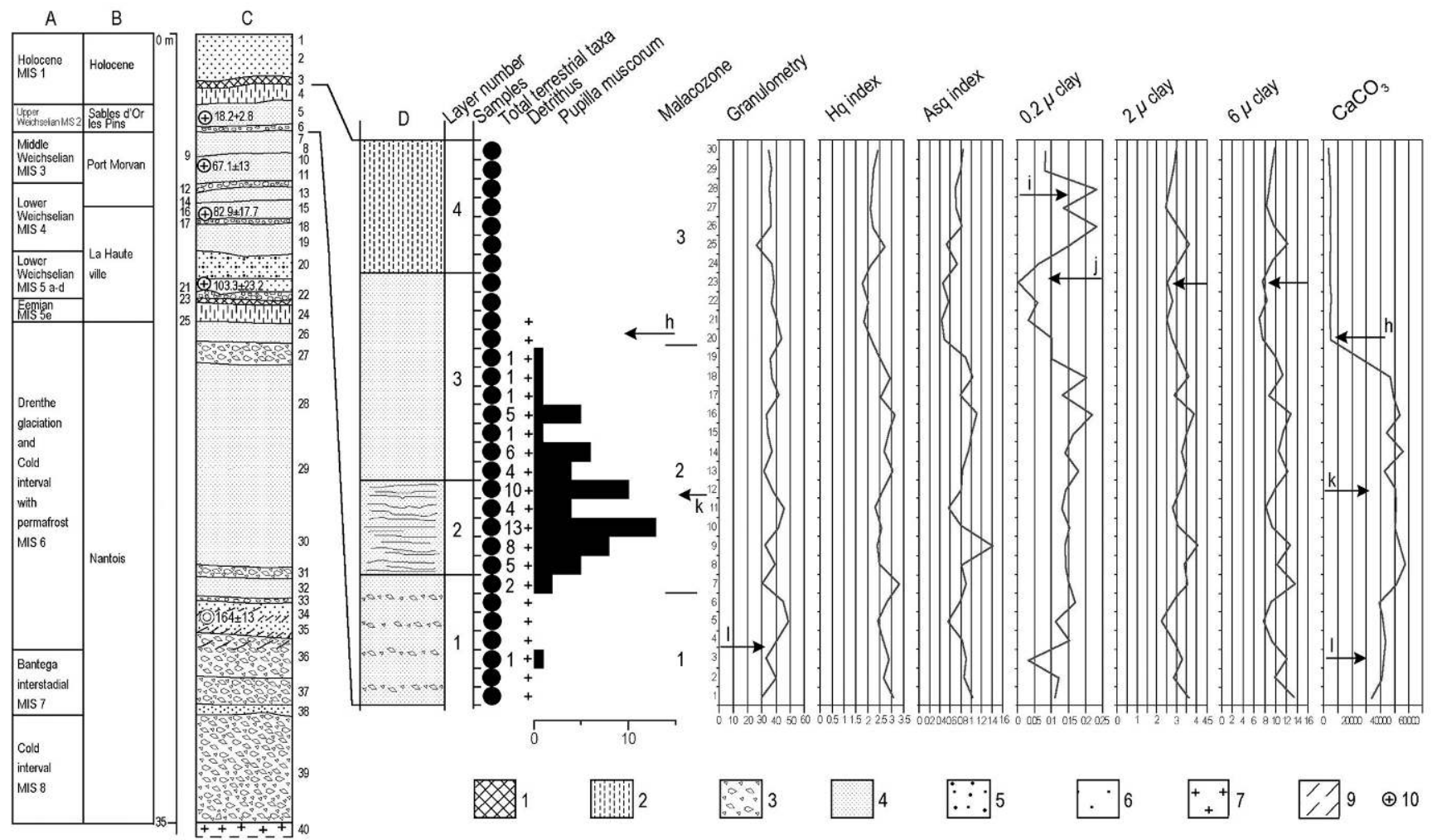

$\oplus 10$

Figure 7: Frequency of terrestrial molluscs, granulometry and calcimetry curves measured in the deposits of Sables-d'Or-les-Pins Formation (Upper Pleistocene) of the Nantois site and possible attribution to the regional (A) and general (B) stratigraphical schemes used in this paper. C Section: Nantois loess: paleosol sequence according to Monnier (1973) and Laforge (2012): small Arabic numbers indicate the numbering of the lithological units. D Section: investigated loess interval (Weichselian), mollusc occurance, granulometry and calcimetry data. See figure 6 for the other symbols.

Figure 7 : Fréquence des mollusques terrestres, granulométrie et calcimétrie mesurées dans la Formation de Sables-d'Or-les-Pins (Pléistocène Supérieur) du site de Nantois et corrélation possible avec le schéma stratigraphique régional (A) et général (B) utilisés dans cette publication. Section C : Loess de la section de Nantois : séquence de paléosols d'après Monnier (1973) et Laforge (2012) : les petits chiffres arabes indiquent la numérotation des unités lithologiques. Coupe D: section de loess étudiés (Weichselien), présence de mollusques, données granulométriques et calcimétrie. Voire la figure 6 pour les autres symboles. 


\begin{tabular}{|c|c|c|c|c|c|c|c|c|c|c|c|c|c|c|}
\hline 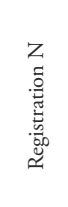 & 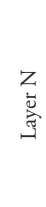 & 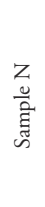 & 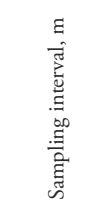 & 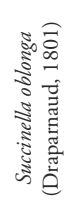 & 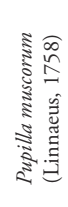 & 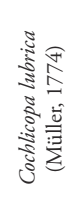 & 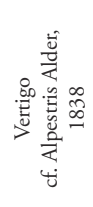 & 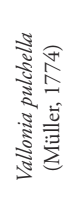 & 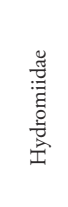 & 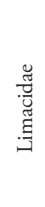 & 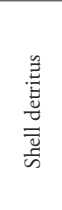 & 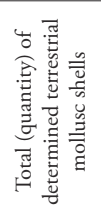 & 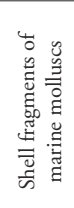 & 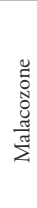 \\
\hline 3728 & \multirow{3}{*}{2} & 1 & $0-0,10$ & & 46 & & & & & 2 & 1 & 48 & & \multirow{10}{*}{1} \\
\hline 3729 & & 2 & $0,10-0,20$ & & & & & & & & 8 & & & \\
\hline 3730 & & 3 & $0,20-0,30$ & & 1 & & & & & & 168 & 1 & 16 & \\
\hline 3731 & \multirow{2}{*}{3} & 4 & $0,30-0,40$ & & & & & & & & 65 & & & \\
\hline 3732 & & 5 & $0,40-0,50$ & & 1 & & & & & & 130 & 1 & 3 & \\
\hline 3733 & \multirow{10}{*}{4} & 6 & $0,50-0,60$ & & 5 & & & & & & 29 & 5 & 3 juv. & \\
\hline 3734 & & 7 & $0,60-0,70$ & & 1 & & & & & & 46 & 1 & 1 & \\
\hline 3735 & & 8 & $0,70-0,80$ & & 4 & & & & & & 28 & 4 & 5 & \\
\hline 3736 & & 9 & $0,80-0,90$ & & 5 & & & & & & 29 & 5 & 1 & \\
\hline 3737 & & 10 & $0,90-1,00$ & & 5 & & & & & & + & 5 & & \\
\hline 3738 & & 11 & $1,00-1,10$ & & 9 & & & & & & 13 & 9 & 1 & \multirow{4}{*}{2} \\
\hline 3739 & & 12 & $1,10-1,20$ & & 53 & 1 & & & & & 42 & 54 & 2 & \\
\hline 3740 & & 13 & $1,20-1,30$ & & 148 & & 1 & & & 1 & 12 & 150 & & \\
\hline 3741 & & 14 & $1,30-1,40$ & & 2 & & & & 1 juv. & & 30 & 3 & & \\
\hline 3742 & & 15 & $1,40-1,50$ & & & & & & & & 228 & & & \multirow{10}{*}{3} \\
\hline 3743 & \multirow{7}{*}{5} & 16 & $1,50-1,60$ & & & & & & & & 82 & & & \\
\hline 3744 & & 17 & $1,60-1,70$ & & & & & & & & 102 & & & \\
\hline 3745 & & 18 & $1,70-1,80$ & & 1 & & & & & & 246 & 1 & 3 & \\
\hline 3746 & & 19 & $1,80-1,90$ & & & & & & & & 39 & & & \\
\hline 3747 & & 20 & $1,90-2,00$ & & 3 & & & & & & 86 & 3 & & \\
\hline 3748 & & 21 & $2,00-2,10$ & & 1 & & & & & & 39 & 1 & & \\
\hline 3749 & & 22 & $2,10-2,20$ & & 2 & & & & & & 6 & 2 & & \\
\hline 3750 & \multirow{2}{*}{6} & 23 & $2,20-2,30$ & & & & & & & & 10 & & & \\
\hline 3751 & & 24 & $2,30-2,40$ & & & & & & & & 7 & & 1 & \\
\hline 3752 & \multirow{2}{*}{7} & 25 & $2,40-2,50$ & & 3 & & & & & & 53 & 3 & 1 & \multirow{5}{*}{4} \\
\hline 3753 & & 26 & $2,50-2,60$ & & 1 & & & & 1 juv. & & 5 & 2 & & \\
\hline 3754 & \multirow{3}{*}{8} & 27 & $2,60-2,70$ & & 2 & & & 1 & & & 2 & 3 & & \\
\hline 3755 & & 28 & $2,70-2,80$ & & 7 & & & & 2 juv. & & 80 & 9 & 6 & \\
\hline 3756 & & 29 & $2,80-2,90$ & & 55 & & & 6 & 19 & 1 & 390 & 81 & & \\
\hline 3757 & \multirow{9}{*}{9} & 30 & $2,90-3,00$ & 1 & 5 & & & & & & 48 & 6 & & \\
\hline & & 31 & $3,00-3,10$ & & & & & & & & & & & \\
\hline 3758 & & 32 & $3,10-3,20$ & & & & & & & & 2 & & & \\
\hline & & 33 & $3,20-3,30$ & & & & & & & & & & & \\
\hline & & 34 & $3,30-3,40$ & & & & & & & & & & & \\
\hline \multirow{16}{*}{3759} & & 35 & $3,40-3,50$ & & & & & & & & & & & \\
\hline & & 36 & $3,50-3,60$ & & & & & & & & 2 & & & \\
\hline & & 37 & $3,60-3,70$ & & & & & & & & & & & \\
\hline & & 38 & $3,70-3,80$ & & & & & & & & & & & \\
\hline & \multirow{11}{*}{10} & 39 & $3,80-3,90$ & & & & & & & & & & & 5 \\
\hline & & 40 & $3,90-4,00$ & & & & & & & & & & & \\
\hline & & 41 & $4,00-4,10$ & & & & & & & & & & & \\
\hline & & 42 & $4,10-4,20$ & & & & & & & & & & & \\
\hline & & 43 & $4,20-4,30$ & & & & & & & & & & & \\
\hline & & 44 & $4,30-4,40$ & & & & & & & & & & & \\
\hline & & 45 & $4,40-4,50$ & & & & & & & & & & & \\
\hline & & 46 & $4,50-4,60$ & & & & & & & & & & & \\
\hline & & 47 & $4,60-4,70$ & & & & & & & & & & & \\
\hline & & 48 & $4,70-4,80$ & & & & & & & & & & & \\
\hline & & 49 & $4,80-4,90$ & & & & & & & & & & & \\
\hline & & & Total & 1 & 360 & 1 & 1 & 7 & 23 & 4 & 2018 & 397 & 43 & \\
\hline
\end{tabular}

Table 2: Composition of the mollusc species found in the Nantois site, Nantois Formation (Saalian, Late Middle Pleistocene). Legend: + - shell fragments with size less than $1 \mathrm{~mm}$; juv. - juvenile mollusc shell.

Tableau 2 : Espèces de mollusques trouvées dans le site de Nantois, Formation de Nantois (Saalien, Pléistocène Moyen Terminal). Légende : + - fragments de coquilles dont la taille est inférieure à $1 \mathrm{~mm}$; juv. - coquilles de mollusques juvéniles. 


\begin{tabular}{|c|c|c|c|c|c|c|c|c|c|c|}
\hline 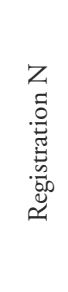 & 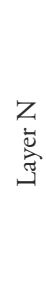 & 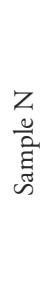 & 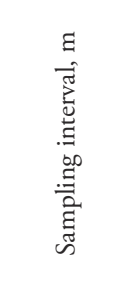 & 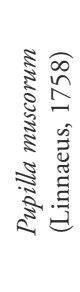 & $\begin{array}{l}\dot{0} \\
\frac{3}{3} \\
\frac{1}{3}\end{array}$ & 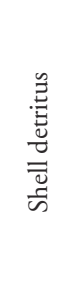 & 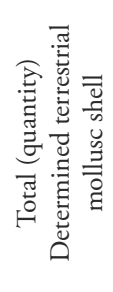 & 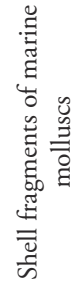 & 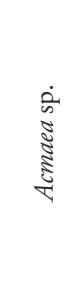 & 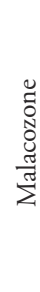 \\
\hline 3850 & \multirow{7}{*}{1} & 1 & $0-0,10$ & & & 90 & & 1 & & \multirow{6}{*}{1} \\
\hline 3851 & & 2 & $0,10-0,20$ & & & 117 & & & 1 & \\
\hline 3852 & & 3 & $0,20-0,30$ & & 1 & 85 & 1 & & & \\
\hline 3853 & & 4 & $0,30-0,40$ & & & 151 & & 5 & & \\
\hline 3854 & & 5 & $0,40-0,50$ & & & 193 & & & & \\
\hline 3855 & & 6 & $0,50-0,60$ & & & 198 & & & & \\
\hline 3856 & & 7 & $0,60-0,70$ & & 2 & 175 & 2 & & & \multirow{15}{*}{2} \\
\hline 3857 & \multirow{5}{*}{2} & 8 & $0,70-0,80$ & & 5 & 152 & 5 & 3 & & \\
\hline 3858 & & 9 & $0,80-0,90$ & 8 & & 261 & 8 & & & \\
\hline 3859 & & 10 & $0,90-1,00$ & 13 & & 190 & 13 & & & \\
\hline 3860 & & 11 & $1,00-1,10$ & 4 & & 265 & 4 & 1 & & \\
\hline 3861 & & 12 & $1,10-1,20$ & 10 & & 151 & 10 & & & \\
\hline 3862 & \multirow{11}{*}{3} & 13 & $1,20-1,30$ & 4 & & 86 & 4 & & & \\
\hline 3863 & & 14 & $1,30-1,40$ & 6 & & 57 & 6 & & & \\
\hline 3864 & & 15 & $1,40-1,50$ & 1 & & 20 & 1 & & & \\
\hline 3865 & & 16 & $1,50-1,60$ & 5 & & 76 & 5 & 1 & 1 juv. & \\
\hline 3866 & & 17 & $1,60-1,70$ & 1 & & 79 & 1 & & & \\
\hline 3867 & & 18 & $1,70-1,80$ & & 1 juv. & 58 & 1 & & & \\
\hline 3868 & & 19 & $1,80-1,90$ & & 1 & 14 & 1 & & & \\
\hline 3869 & & 20 & $1,90-2,00$ & & & 5 & & & & \\
\hline \multirow[t]{11}{*}{3870} & & 21 & $2,00-2,10$ & & & 1 & & & & \\
\hline & & 22 & $2,10-2,20$ & & & & & & & \multirow{9}{*}{3} \\
\hline & & 23 & $2,20-2,30$ & & & & & & & \\
\hline & \multirow{7}{*}{4} & 24 & $2,30-2,40$ & & & & & & & \\
\hline & & 25 & $2,40-2,50$ & & & & & & & \\
\hline & & 26 & $2,50-2,60$ & & & & & & & \\
\hline & & 27 & $2,60-2,70$ & & & & & & & \\
\hline & & 28 & $2,70-2,80$ & & & & & & & \\
\hline & & 28 & $2,80-2,90$ & & & & & & & \\
\hline & & 30 & $2,90-3,00$ & & & & & & & \\
\hline & & & Total & 52 & 10 & 2424 & 62 & 11 & 2 & \\
\hline
\end{tabular}

Table 3: Composition of the mollusc species found in the Nantois site, Sables-d'Or-les-Pins Formation (Upper Weichselian, Upper Pleistocene).

Legend: + - shell fragments with size less than $1 \mathrm{~mm}$; juv. - juvenile mollusc shell.

Tableau 3 : Espèces de mollusques trouvées dans le site de Nantois, Formation de Sables-d'Or-les-Pins (Pléistocène Supérieur).

Légende: + - fragments de coquilles dont la taille est inférieure à $1 \mathrm{~mm}$; juv. - coquilles de mollusques juvéniles.

\section{Systematic composition analysis}

The examined shells only belong to one class of Gastropods. The samples include terrestrial mollusc shells (6 species, 5 genera) but also numerous fine shell detritus. The mollusc species composition is shown in tables 2 and 3.
A total amount of 397 terrestrial mollusc shells (and 2018 fragments) belonging to 7 species were identified in the Late Middle Pleistocene deposits of Nantois (Succinella oblonga (Draparnaud, 1801), Pupilla muscorum (Linnaeus, 1758), Cochlicopa lubrica (Müller, 1774), Vertigo cf. alpestris Alder, 
1838, Vallonia pulchella (Müller, 1774), Hydromiidae, Limax sp.) and a total of 62 mollusc shells (and 2424 fragments) belonging to 1 species were identified in the Upper Pleistocene deposits (Pupilla muscorum and Pupilla sp.) (Tables 2 and 3; Figures 6 and 7).

The presence of small detritus of marine shells was also observed in these deposits. Marine molluscs were living in a sea which existed before the cold phases when loess accumulated. During these cold phases the sea was located at a lower level and part of the marine sediments were open to the air. The marine winds, blowing towards the Nantois cliff, were strong enough to carry at the same time, the loess particles and very small fragments of shell and juveniles of marine bivalves or gastropods (Bigot, 1986; Danukalova et al., 2013). Fragments and juvenile shells of marine molluscs are difficult to determine because of their bad preservation, only Acmaea sp., Peringia sp., Muricidae (possibly Ocenebra sp.), Trochidae, Ostrea sp. and Cardiidae were present amongst the studied fragments

The dominant and single species found in Sables-d'Orles-Pins loess is Pupilla muscorum. The dominant species recognized in Nantois loess is also Pupilla muscorum, the second prevailing species are Hydromiidae and Vallonia pulchella. Species of Succinella, Vertigo, Cochlicopa and slug shells are rare.

Pupilla (Figures 8, 9, 11). This genus is represented by numerous shells of $P$. muscorum species in the Sables-d'Orles-Pins Formation (52 individuals) and Nantois Formation (360 individuals). In both Formations the morphology of the shells is similar. The shape of the shells is spiral conical (ovalcylindrical) with evenly convex weakly striated 5-6 whorls. The shells of the Nantois Formation have more solid walls than the shells of Sables-d'Or-les-Pins Formation which are thinner and more fragile. When we compare the thickness of the walls of the shells with the results of the carbonates analysis we can notice that the calcium carbonate content in the Nantois sediments (level 1.2-1.3 m) is of 6000-7000 ppm, and that of the Sables-d'Or-les-Pins Formation is less than 5000-5500 ppm (level 0.9-1 m). Whorls are well separated by well-marked and not very deep suture. The mean characteristics of the shells of the Nantois deposits are as follow: shell length: $3.5 \mathrm{~mm}$, width: $1.8 \mathrm{~mm}$, coefficient of elongation (width / length): 0.46 . The mean characteristics of the shells from Sables-d'Or-les-Pins deposits are: shell length: $3.5 \mathrm{~mm}$, width: $1.7 \mathrm{~mm}$, coefficient of elongation: 0.5 . It must be noted that the shells of the Nantois Formation are oval-cylindrical, and differently elongated (the height ranging from 2.8 to $4.2 \mathrm{~mm}$ ). We assume that this discrepancy is due to the differences in age (adult or juvenile) of the studied molluscs. The aperture is irregularly semi-circular with well developed lips turned towards the outside, with well developed cervical callus on the palatal side (like the constriction and the dam above it) and with a parietal tooth which is better developed in the apertures of Pupilla shells collected in the Nantois loess than in the Sables-d'Or-les-Pins deposits (Likharev \& Rammelmeier, 1952, p. 146, fig. 59; Danilovskyi, 1955, p. 96, tabl. 7, fig. 177-182; Ložek, 1964, p. 215, tabl. 9, fig. 1, 7; Shileyko, 1984, p. 179, fig. 97; Kerney, Cameron, 1999, p. 120).

Succinella (Figure 9). Only one juvenile shell badly preserved represents this genus (Nantois Formation). This shell is spiral conical and weakly striated with convex and rapidly increasing whorls (3) well separated by a well-marked deep suture. The last whorl is two times larger than the former one and is almost destroyed on the studied specimen as well as its aperture. The characteristics of the shell are: shell length: $3.5 \mathrm{~mm}$, width: $1.9 \mathrm{~mm}$. This shell probably belongs to $S$. oblonga (Likharev \& Rammelmeier, 1952, p. 122-123, fig. 32; Danilovskyi, 1955, p. 87, tabl. 5, fig. 93, 101, 103-107, 108, 109; Ložek, 1964, p. 230, table 12, fig. 7-9; Shileyko and Likharev, 1986, p. 200, fig. 1; Sysoev \& Shileyko, 2009, fig. 5, F; Kerney \& Cameron, 1999, p. 98, pl. 2, fig. 2).

Vallonia (Figure 10). Seven shells from this genus were recognized in the Nantois Formation. The shells are circular, spiral low conical with slow increased $3 \frac{1}{4}-3^{3} / 4$ convex whorls separated by a well-marked deep suture. The last whorl is wider than the previous one and does not fall to the mouth. The mean characteristics of the shells are: shell length: $1.3 \mathrm{~mm}$, width: $2.5 \mathrm{~mm}$. The aperture is circular; its attachment places are close to each other. The outer side is retracted outward and is thickening with a white lip; the inner edge is thin and adjacent to the shell surface. The umbilicus is wide. The specimens belong to $V$. pulchella (Likharev \& Rammelmeier, 1952, p. 164, fig. 77; Danilovskyi, 1955, p. 88, tabl. 6, fig. 117-118; Ložek, 1964, p. 221, tabl. 10, fig. 5 a-c; Shileyko, 1984, p. 166, fig. 92, III; Sysoev and Shileyko, 2009, fig. 16, C; Kerney \& Cameron, 1999, p. 127).

Vertigo (Figure 9). Only one adult shell represents this genus (Nantois Formation). The shape of the shell is spiral conical (oval-cylindrical) with evenly convex weakly striated progressively increased $43 / 4$ whorls. The characteristics of the shell are: shell length: $2.1 \mathrm{~mm}$, width: $1.2 \mathrm{~mm}$. The aperture is irregularly semi-circular with well-developed lips turned out, with developed cervical callus at the palatal side (it can be absent) and with four teeth: one parietal, one columellar and two palatal. This shell probably belongs to Vertigo cf. alpestris (Shileyko 1984, p. 211, fig. 133, I; Sysoev \& Shileyko, 2009, fig. 20, G, H). 


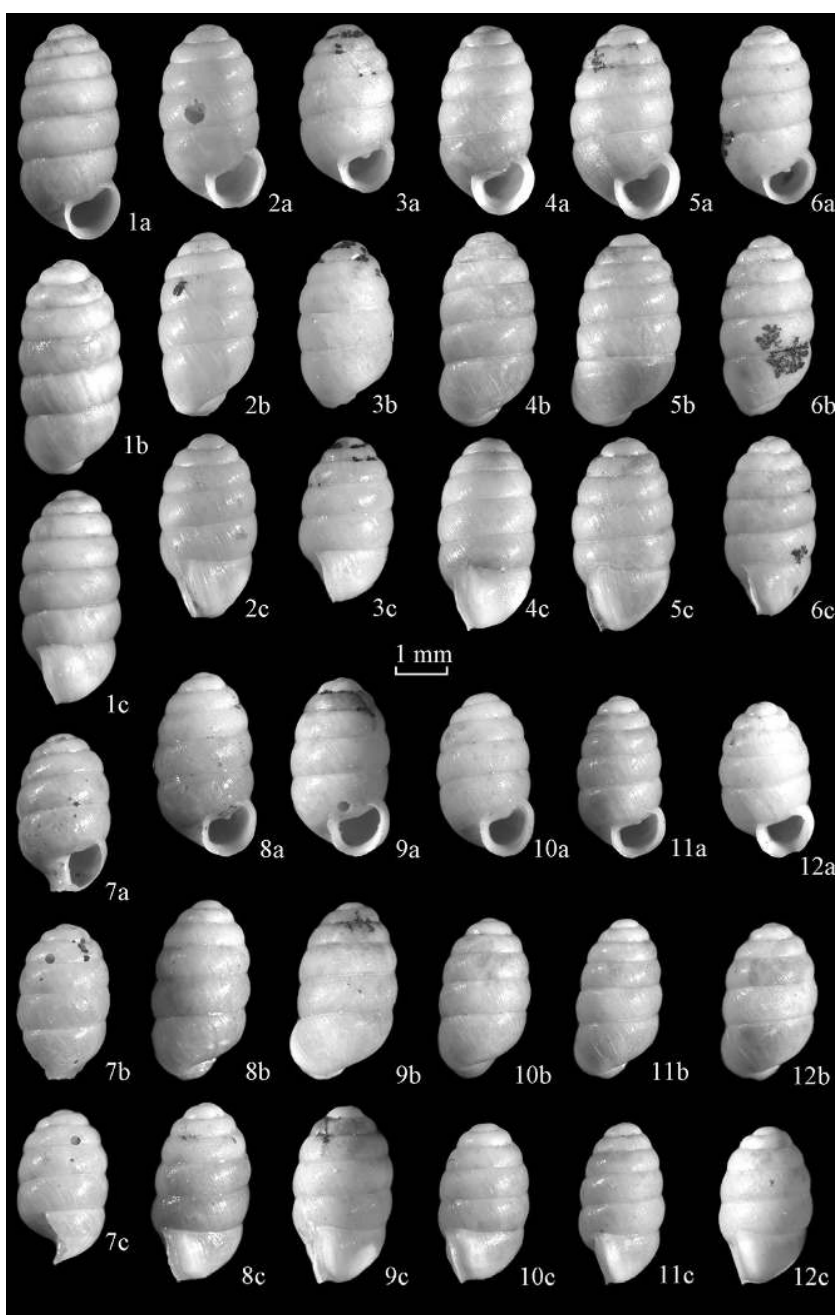

Figure 8: (See colour plate XVIII) Pupilla muscorum (L.) found in the Nantois site, Brittany, France (Nantois Formation, late Middle Pleistocene): 1: IG $\mathrm{n}^{\circ} 183 / 3728 / 1$, section 1 , depth 0-0.1 m; 2: IG $\mathrm{n}^{\circ} 183 / 3733 / 1$, section 1, depth 0.5-0.6 m; 3: IG n ${ }^{\circ} 183 / 3734 / 1$, section 1, depth 0.6-0.7 m; 4: IG n ${ }^{\circ} 183 / 3737 / 1$, section 1 , depth 0.9-1.0 m; 5: IG n ${ }^{\circ}$ 183/3739/1, section 1, depth 1.1-1.2 m; 6: IG $\mathrm{n}^{\circ}$ 183/3741/1, section 1, depth 1.3-1.4 m; 7: IG n ${ }^{\circ} 183 / 3745 / 1$, section 1, depth 1.7-1.8 m; 8: IG $\mathrm{n}^{\circ}$ 183/3753/1, section 1 , depth 2.5-2.6 m; 9: IG n ${ }^{\circ}$ 183/3754/1, section 1, depth 2.6-2.7 m; 10 : IG $\mathrm{n}^{\circ} 183 / 3755 / 1$, section 1 , depth 2.7-2.8 m; 11 : IG $\mathrm{n}^{\circ} 183 / 3756 / 1$, section 1 , depth 2.8-2.9 m; 12: IG n ${ }^{\circ}$ 183/3757/1, section 1, depth 2.9-3.0 m; a - apertural view; b - abapertural view (view from the opposite side of the aperture); c - lateral view (top right); IG ${ }^{\circ} 183 / 3858 / 1$ : specimen number recorded in the Institute of Geology USC RAS (Ufa) mollusc base.

Figure 8: (Voir planche couleur XVIII) Pupilla muscorum (L.) trouvés dans le site de Nantois, Bretagne, France (Formation de Nantois, Pléistocène moyen terminal). Voir le texte anglais pour les références.

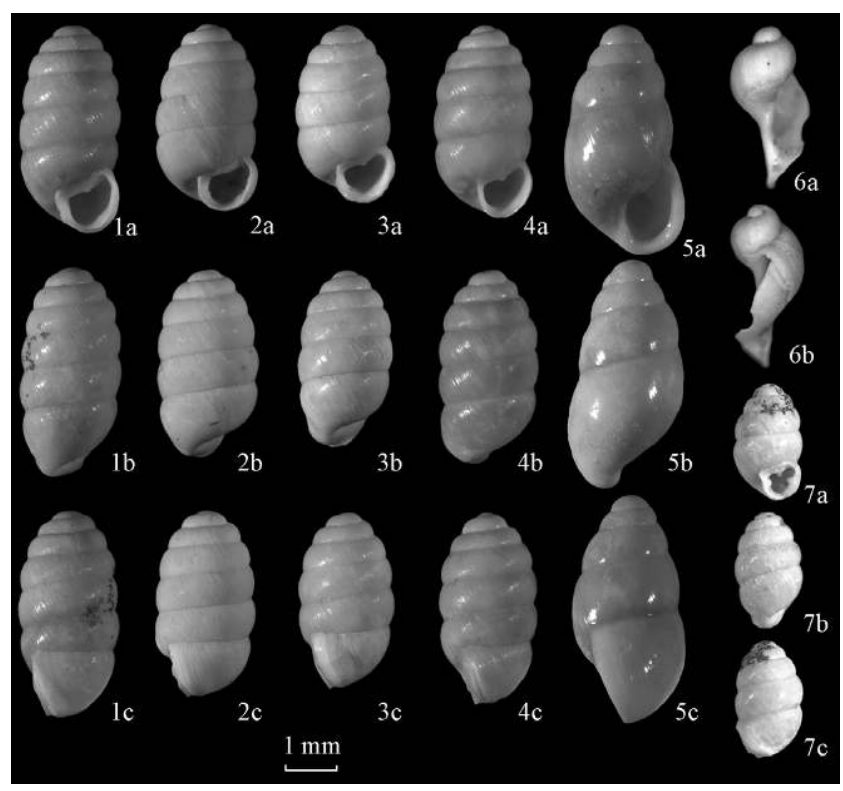

Figure 9: (See colour plate XVIII) Mollusc shells found in the Nantois site, Brittany, France (Nantois Formation, late Middle Pleistocene): Pupilla muscorum (L.) 1: IG n ${ }^{\circ}$ 183/3740/1, section 1, depth 1.2-1.3 m; 2: IG n ${ }^{\circ} 183 / 3740 / 2$, section 1, depth 1.2$1.3 \mathrm{~m}$; 3: IG $\mathrm{n}^{\circ} 183 / 3740 / 3$, section 1 , depth 1.2-1.3 m; 4: IG $\mathrm{n}^{\circ} 183 / 3740 / 4$, section 1, depth 1.2-1.3 m; Cochlicopa lubrica (Müll.): 5: IG n ${ }^{\circ}$ 183/3739/1, section 1, depth 1.1-1.2 m; Succinella oblonga (Drap.): 6: IG $\mathrm{n}^{\circ}$ 183/3757/2, section 1, depth 2.9-3.0 m; Vertigo cf. alpestris Alder, 1838: 7: IG n ${ }^{\circ}$ 183/3740/1, section 1, depth 1.2-1.3 m; a - apertural view; b - abapertural view (view from the opposite side of the aperture); c: lateral view (top right).

Figure 9: (Voir planche couleur XVIII) Coquilles de mollusques trouvées dans le site de Nantois, Bretagne, France (Formation de Nantois, Pléistocène moyen terminal). Voir le texte anglais pour les références.

Cochlicopa (Figure 9). Only one shell of Cochlicopa lubrica was found in the Nantois Formation. The shell has a spiral conical shape with rounded apex, with $41 / 2$ convex whorls subdivided by a deep suture. The shell has a shinning surface. The characteristics of the shell are: shell height: $4.1 \mathrm{~mm}$, width: $2 \mathrm{~mm}$. The aperture is oval, the parietal side is cut, and the other sides are slightly thickened. The aperture has no teeth. This shell probably belongs to a juvenile mollusc (Likharev \& Rammelmeier, 1952, p. 125, fig. 35; Danilovskyi, 1955, p. 97, tabl. 8, fig. 193-197, 205; Ložek, 1964, p. 193, tabl. 5, fig. 7, 8; Shileyko, 1984, p. 211, fig. 44, III; Sysoev \& Shileyko, 2009, fig. 8, E; Kerney \& Cameron, 1999, p. 97, pl. 1, fig. 11).

Limacidae (Figure 10). Four reduced shells of Limacidae have been found in the Nantois Formation (Section 1). The shape of the shell is oblong-oval and thin slightly convex 


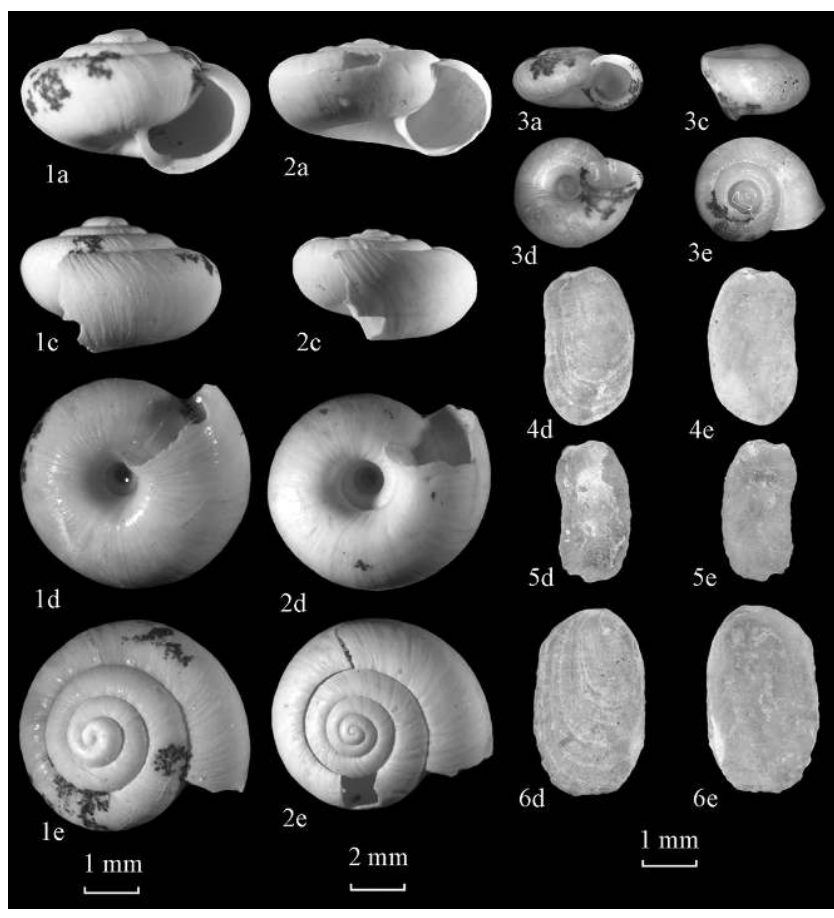

Figure 10: (See colour plate XIX) Mollusc shells found in the Nantois site, Brittany, France (Nantois Formation, late Middle Pleistocene): Hidromiidae (L.): 1: IG $\mathrm{n}^{\circ}$ 183/3741/1, section 1, depth 1.3-1.4 m; 2: IG no 183/3756/1, section 1, depth 2.8-2.9 m; Vallonia pulchella (Müll.): 3: IG n ${ }^{\circ} 183 / 3754 / 1$, section 1, depth 2.6-2.7 m; Limacidae: 4: IG ${ }^{\circ} 183 / 3728 / 1$, section 1, depth 0-0.1 m; 5: IG n ${ }^{\circ} 183 / 3728 / 2$, section 1 , depth 0-0.1 m; 6: IG $\mathrm{n}^{\circ} 183 / 3740 / 5$, section 1 , depth 1.2-1.3 m; a: apertural view; c: lateral view (top right); d: umbilical view; e: apical view.

Figure 10: (Voir planche couleur XIX) Coquilles de mollusques trouvées dans le site de Nantois, Bretagne, France (Formation de Nantois, Pléistocène moyen terminal).

with an inflated apex at the posterior margin but inclined towards the left side. The medium length of the shell is $3.1 \mathrm{~mm}$, width $-1.8 \mathrm{~mm}$. All shells probably belong to the genus Limax (Steklov, 1966, p. 219, tabl. 9, fig. 175-177).

Hydromiidae (Figure 10). Twenty three juvenile fragile shells of a bad and poor preservation coming from the Nantois loess were studied. The general morphologies of these shells are similar but show some slight differences, it is why they have been subdivided in two groups. The photos illustrating these groups are shown on Fig. 13, 1 and 2. The shells have a spiral low conical depressed shape (the height of the spire is less that the height of the aperture according to Shileyko, 1978, fig. 2) with weakly striated $33 / 4-43 / 4$ convex whorls, separated by a deep suture. The spire is rounded; its height is $0.6 \mathrm{~mm}$ (group 1) or $0.4 \mathrm{~mm}$

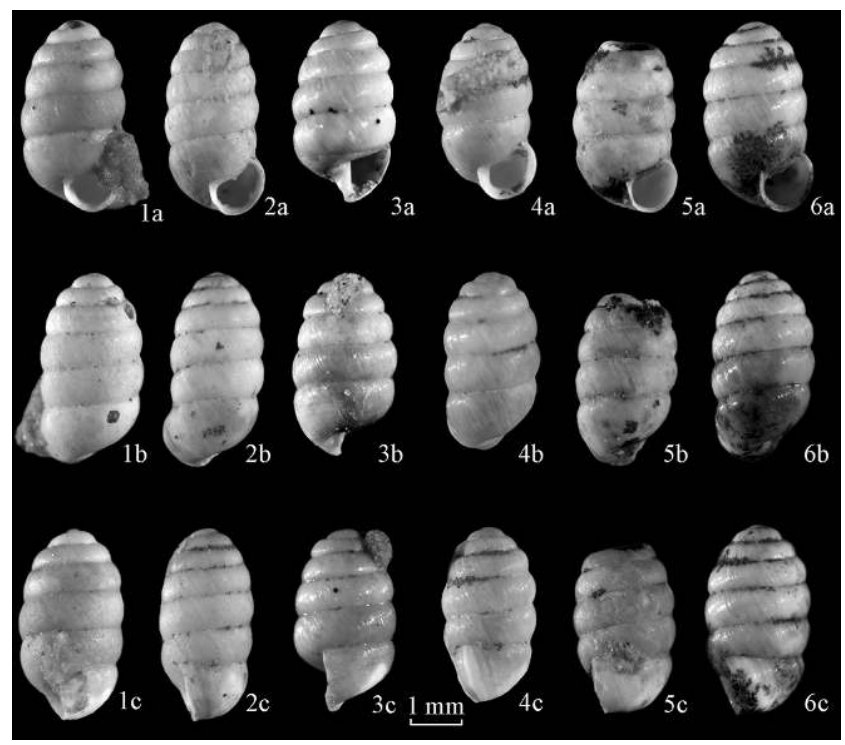

Figure 11: (See colour plate XIX) Pupilla muscorum (L.) found in the Nantois site, Brittany, France (Sables-d'Or-les-Pins Formation, Upper Pleistocene): 1: IG $\mathrm{n}^{\circ} 183 / 3858 / 1$, section 2, depth 0.8 $0.9 \mathrm{~m} ; 2$ : IG $\mathrm{n}^{\circ} 183 / 3859 / 1$, section 2, depth 0.9-1.0 m; 3: IG $\mathrm{n}^{\circ} 183 / 3860 / 1$, section 2, depth 1.0-1.1 m; 4: IG n ${ }^{\circ} 183 / 3861 / 1$, section 2, depth 1.1-1.2 m; 5: IG n ${ }^{\circ} 183 / 3863 / 1$, section 2, depth 1.3-1.4 m; 6: IG n ${ }^{\circ} 183 / 3865 / 1$, section 2, depth 1.5-1.6 m; a: apertural view; b: abapertural view (view from the opposite side of the aperture); c: lateral view (top right); IG $\mathrm{n}^{\circ}$ 182/3858/1: specimen number recorded in the mollusc base of the Institute of Geology USC RAS (Ufa).

Figure 11 : (Voir planche couleur XIX) Pupilla muscorum (L.) trouvés dans le site de Nantois, Bretagne, France (Formation de Sablesd'or-les-pins, Pléistocène Supérieur).

(group 2). The last (= body) whorl is rounded (group 1) or is slightly angular at the beginning (group 2). All the samples display a destroyed aperture. The characteristics of the shells are: shell height: $4.1 \mathrm{~mm}$, width: $2.6 \mathrm{~mm}$; the coefficient of elongation is of 0.63 (group 1) or the height is of $8 \mathrm{~mm}$, the width of $4.3 \mathrm{~mm}$ and the coefficient of elongation is 0.54 (group 2). The umbilicus is wide and open. The molluscs of group 2 have a wider umbilicus than the molluscs of group 1. In general the mollusc shells of these two groups differ in elongation, height of spire and shape of the whorls and their relationship with the suture. The shells belong to the family of the Hydromiidae and probably belong to the Trichia genus (Likharev \& Rammelmeier, 1952, p. 450, fig. 377; Danilovskyi, 1955, p. 80, tabl. 3, fig. 57-58; Ložek, 1964, p. 300, tabl. 25, fig. 1 a-c; Kerney \& Cameron, 1999 , p. 241, pl. 19). 


\section{DisCusSION}

\section{Sedimentological interpretation}

The granulometric curves are characteristic of loess sediments (as shown by the Md, Hq and Asq parameters), the asymmetric sigmoid curve being steeper towards the coarse grains. In general the Sables-d'Or-les-Pins loess is slightly coarser than the Nantois loess (Figures 6 and 7).

Sorting is not as good in the Nantois loess since the symmetry of the distribution is slightly less pronounced. Nantois loess appears also to be more heterogeneous than Sables-d'Or-les-Pins loess with higher median variations but with smaller variation of the sorting index. In total the difference between the two loesses can be summarized as follow:

- Nantois loess is relatively thin (mean of the medians: 27 microns; minimum: 14.4 microns; maximum: 37.1 microns; standard deviation: 5.9$)$. They are well sorted (Hq: 2.8; minimum: 2.1; maximum: 3.2; standard deviation: 2.4). They are carbonated and rework foraminiferous, coccoliths and fragments of shells. The sandy fraction is made of a blending of blunted quartz grains (coming from the beaches), of angular quartz grains and of micas flakes probably coming from the rocky slopes. All the grains are clay-coated. Clay is likely inherited from littoral or lacustrine mud-banks. Ca rate in ppm: 32484; minimum: 5052; maximum: 70223; standard deviation: 240105

- Sables-d'Or-les-Pins loess is relatively coarse (mean of the medians: 37.2 microns; maximum: 48.7 microns; minimum: 26; standard deviation: 5.1). Ca rate in ppm: 30963 ; maximum: 57276; minimum: 3970; standard deviation: 21184.

\section{Environmental considerations based on mollusc study}

The groups of molluscs were classified according to their modern ecological preferences in air temperature, humidity, and vegetation cover following the criteria proposed by Ložek (1964), Likharev and Rammelmeier (1952), Sümegi (in Willis et al., 2000) and Puisségur (1976). After analyzing the data and according to the authors experience (Danukalova et al., 2013; Osipova et al., 2013), it has been possible to determine five mollusc zones in Section 1 and three mollusc zones in Section 2.

\section{Nantois Formation (Table 2, Figure 6)}

\section{Malacozone 1}

This zone corresponds with layers 2, 3 and the lower part of the layer 4 (interval 0-1 $\mathrm{m}$ ) and with the samples numbered from 1 to 10. Pupilla muscorum is the dominant species, and is represented almost in all the studied samples; its amount varies between 1 and 5. The sample 1 is the richest sample in shells since it contains 46 shells. Limacidae (Limax sp.) are rare and are only present in the sample 1 . All the samples contain numerous fine shell detritus. The landscape which prevailed during the accumulation of these deposits corresponded with open grassy habitats (tundra, cold meadows or littoral dunes).

\section{Malacozone 2}

This zone corresponds with the upper part of the layer 4 (interval 1-1.4 m) and with the samples numbers 11 to 14 . Pupilla muscorum is the dominant species. There is a large number of shells of this species in the middle part of this interval where a single shell of Cochlicopa lubrica, Vertigo cf. alpestris, Limacidae and Hydromiida were also found. According to the modern presence of mollusc as a function of climates this species was living in mesophilous conditions. The classification of those molluscs according to the present-day humidity rate indicates that all these species are mesophilous and can live in a normal or moderately wet environment. These species preferred an open habitat with well-developed vegetation. During the accumulation of those deposits, the landscape corresponded with wet grassy open habitats probably associated with bushes and trees. Vertigo alpestris - indicates the existence of cold climate conditions. But the Limacidae shells show that the climate around Nantois site was not extremely cold. The mollusc community (Limacidae, Pupilla muscorum, and Cochlicopa lubrica) do not reflect the existence of an extremely cold climate during accumulation of these deposits, and the cooler global environment was only recognized thanks to the presence of Vertigo alpestris.

\section{Malacozone 3}

This zone corresponds with the uppermost part of the layer 4, the layers 5 and 6 (interval 1.4-2.4 $\mathrm{m}$ ) and with the samples numbered between 15 and 24. Pupilla muscorum is the only species present. Complete shells were found mainly in the middle part of this zone. All the samples contain many fine shell detritus. The landscape which prevailed during the accumulation of these deposits may have corresponded with open grassy habitats (tundra, cold meadows or littoral dunes). 


\section{Malacozone 4}

This zone corresponds to the layers 7 and 8 and most of the lower part of layer 9 (interval 2.4-3 m) and with the samples numbered between 25 and 30. Pupilla muscorum stays the dominant species, its abundance increases in the middle part of this zone. Vallonia pulchella, Hydromiida, Limacidae and Succinella oblonga are present. According to the modern mollusc climatic distribution and to the presentday humidity rate all these species preferred from slightly cool to "warm" and wet environments. The landscape, which prevailed during the accumulation of these deposits, corresponded with open habitats rich in vegetation cover.

\section{Malacozone 5}

This zone corresponds with the layers 9 and 10 (interval 3-4.9 m) and with samples numbered between 31 and 49. This zone contains very rare shell detritus in its lower part. The landscape, which probably prevailed during the accumulation of these deposits, corresponded with open habitats.

The presence of numerous fine shell detritus may result from strong winds blowing towards the cliff. The presence of some juvenile shells of marine gastropods observed in those samples supports this idea.

\section{Sables-d'Or-les-Pins Formation (Table 3, Figure 7)}

\section{Malacozone 1}

This zone corresponds with the layer 1 (interval 0-0.6 $\mathrm{m})$ and with the samples numbered between 1 and 6 . The only shell of Pupilla sp. and the shells of marine gastropods were found in this zone. All the samples contain numerous shell detritus. The size of the detritus of all the deposits of Sables-d'Or-les-Pins Formation is coarser than the size of the detritus found in the Nantois Formation.

\section{Malacozone 2}

This zone corresponds with the uppermost part of layer 1 , with layer 2 and with the lower half of layer 3 (interval 0.6-1.9 m) and with samples numbered between 7 and 19 . Pupilla muscorum is the only abundant species found in the middle part of this zone. All the samples contain numerous shell detritus. According to the modern mollusc climatic distribution and the present-day humidity rate all these species preferred cold and dry or slightly wet open habitat. The landscape which prevailed during the accumulation of these deposits corresponded with open grassy habitats (tundra, cold meadows or littoral dunes).

\section{Malacozone 3}

This zone corresponds with the upper half of the layer 3 and with the layer 4 (interval 1.9-3 $\mathrm{m}$ ) and with samples numbered between 20 and 30 . This zone has no complete mollusc shells and contains only rare detritus at the base of this interval.

\section{Integration of the malacological, chemical and physical data collected in the studied sites}

The integration of the malacological observations with the chemical and physical characteristics of the Nantois and Sables-d'Or-les-Pins loess of Nantois site provide interesting information and correlations.

\section{Nantois (late Middle Pleistocene) correlations (Figure 6)}

Before to start any correlation between the various analysis made on the loess we must underline that the physical and chemical analysis we obtained are restricted to the zones where loess and loam were not mixed with fragments of rocks or boulders, the two types of sediments being deposited in different conditions.

The correlations between different data suggest the following comments:

a/ The zone of decalcification almost perfectly fits with the zone where the mollusc shells are absent (or with very rare shell detritus) (f arrows, Figure 6). This decalcification has been explained by the existence of an overlying soil. The dramatic change of the values corresponds with the lower front of alteration of the pedological profile.

$\mathrm{b} /$ The abrupt increase in clay contribution is concentrated in five zones located in the upper part of the sections (a, b, c, d, e alignment of arrows of Figure 6). There is no such a rapid increase in the middle part of the profile. Since we know that the very thin loess particles only deposited when the strong North blowing wind was weakening (Lefort et al., 2013b), we suggest that this phenomenon may corresponds with a small warming episode. This progressive warming can be better appreciated when we notice that the contribution of clays is increasing towards the top of the sections. Unfortunately, we cannot check this interpretation with fauna since there is no more gastropods shells at this level.

$\mathrm{c} /$ The decreasing granulometry front of these abrupt clay contributions is a logical correlation.

$\mathrm{d} /$ The progressive and larger clay contribution in the lowermost part of the clay sections may suggests the same interpretation.

e/ The very large and isolated contribution in terrestrial molluscs in the middle of malacozone 2 perfectly fits with 
the abrupt increase in calcium (g arrows of Figure 6). This observation may suggest that the high calcium values observed in the lower part of the section is associated with the accumulation of dead shells. However, when we compare the amplitude of this maximum with the calcium values reported in the middle part of the section where shells are very few, we must conclude that the calcium contribution is mainly associated with the calcareous dust contained in the loess and that only a small part of it is associated with the dead shells. This very high value is also clearly the result of the downward migration of the calcium, which precipitated at this level as shown by the many calcareous concretions observed at this depth.

\section{Sables-d'Or-les-Pins (late Late Pleistocene) correlations (Figure 7)}

Some of the correlations made for the Nantois loess are also present on the Late Pleistocene data:

a/ Here again, the zone of decalcification almost perfectly fits with the zone where the mollusc shells are absent (h arrows, Figure 7). This decalcification has been explained by the presence of a younger overlying soil. The abrupt change in the calcium values corresponds with the lower front of alteration of the paleosoil profile. This depth which is reaching $1.25 \mathrm{~m}$ is the same for the Middle and Late Pleistocene loess.

$\mathrm{b} /$ The contribution of the clay particles is getting larger for all the sizes of particles towards the top of the analyzed loess. But the larger contribution of the smallest particles (0.2 microns) (i arrow, Figure 7) is closer to the top of the sections which suggests a weakening of the winds and thus the beginning of a warming episode (see explanation given for the Nantois loess). It is interesting to observe that the deposition of the coarser clays occurred earlier in the stratigraphic column which supports the weakening wind explanation.

c/ On the contrary, the low concentrations in clay observed below (mainly expressed by the 0.2 micron clay $-j$ arrows, Figure 7) suggests stronger winds and thus a slightly cooler period.

d/ The maximum calcium concentration just fall front of the maximum concentration of shells. But here again this maximum is more likely related with a downward migration of calcium than to the enrichment in shells, this is supported by the very few shells found at this level.

e/ The lower concentration in calcium observe below (l arrows, Figure 7 ) fits with a coarser granulometric level and thus with the presence of a higher amount of non-calcareous sand grains.

\section{Rapid comparison with other loess deposits known in a few adjacent areas}

\section{Southern England}

In southern England the Late Pleistocene (Late Devensian, MIS 2) loess is widespread and may reach maximum thicknesses of about $4 \mathrm{~m}$. So far as the age is concerned and just to give two well studied examples: at Pegwell Bay site (East Kent) and Skipsea Till site (Yorkshire) loess have been dated between 18.8 and $14.6 \mathrm{Ka}$ by TL methods (Madgett \& Catt, 1978; Wintle, 1981; Parks \& Rendell, 1992; Bateman, 1998; Antoine et al., 2003).

In this area the loess deposits attributed to the MIS 6 stage are thin and discontinuous and represent the remnants of an originally more extensive covers (Parks and Rendell, 1992; Antoine et al., 2003).

\section{Northern and Northeastern France}

In northern and northeastern France Late Pleistocene loess is widespread and reaches up to $12 \mathrm{~m}$ in thickness. The typical calcareous loess known in this region is attributed to the Late Weichselian and dated between 15 and $25 \mathrm{ka}$ (Antoine et al., 2003). The molluscs characteristic of the Late Pleistocene cold climates are known in several sites in Brittany, Normandy and the Channel Islands (Keen, 1982, 1986 a and b; Keen et al., 1997; Danukalova et al., 2013). The malacofauna is usually poor and includes the species Pupilla muscorum, Trichia hispida, Succinella oblonga, and Columella columella. A list of the sites where the Weichselian deposits contain mollusc fauna can be found in Moine (2008).

The loess of the late Middle Pleistocene of northern and northeastern France is usually restricted to fluvial and marine terraces exposed to the east and northeast. This loess is represented by more sandy facies originating in local fluvial beds (Sommé, 1980; Lautridou, 1985; Antoine, 1990; Lebret \& Lautridou, 1991; Antoine et al., 2003). Middle Pleistocene loess is known at Saint-Pierre-les-Elbeuf, Garenne, Mautort, Grâce and some other sites in Normandy and in the Somme River basin (Lautridou \& Puissegur, 1977; Haesaerts \& Dupuis, 1986; Balescu, 1988; Antoine, 1994; Antoine et al., 1998, 2000, 2003).

Closer to the site we studied, Monnier $(1973,1974)$ found very small remnants of late Middle Pleistocene loess equivalent to the upper part of the Nantois Formation, in the Saint Brieuc Bay (Northern Brittany - France). They are known in the sites of Piégu and Les Vallées and were studied for malacology by Keen et al. (1997), there the fauna is dominated by P. muscorum. 


\section{Conclusion}

Study of the physical, chemical and environmental parameters of Nantois loess shows that the Middle and Late Pleistocene loesses were deposited in different conditions even if they display a few common characteristics.

The upper part of the Middle and Late Pleistocene loess are both characterized by the complete absence of molluscs. This can be explained by the influence of the soils which covered both loess and reworked their upper layers. They also evidence the presence of thin clay deposits just before the head formation corresponding with a weakening of the cold winds coming from the North and thus the beginning of a warming episode. At last, they both show on top the existence of gley horizons which suggests the presence of open habitats (tundra?) with cold grassy vegetation.

The older loess (Nantois Formation) which is about 5 meters thick is well sorted and partly made of silty carbonates which explain many carbonate concretions found in some levels. The quartz of the silty part is made of a mixture angular grains + micas probably coming from the hill slope and of smoothed grains coming from the neighboring beach. A thin clay deposit that may come from the littoral marshes covers all the grains. The top of the formation is affected by a head (warming) showing that solifluxion restarted. The beginning of the warming episode, starting before the top of the loess, is shown by the deposition of very thin clay particles related with the weakening of the winds. This formation ends by an illuvial pedogenesis called the "double stripped loam". There is no clear evidence of any pergelisoil. This loess is reworking foraminiferous or coccoliths coming from the chalk of the English Channel and shells and pieces of shells. This older loess is characterized by a rather large variety of mollusc species. The analysis of the mollusc distribution indicates for the first time three moderate climatic phases during the sedimentation.

The new loess (Late Pleistocene) is about 3 meters thick. It is made of silty layers ending by homogeneous carbonated loess. It is well sorted but coarser than the Upper Saalian loess. It also incorporates foraminiferous and pieces of mollusc shells but with a much smaller amount of species. At the end of the deposit, there are more and more micas and pieces of organic matter with traces of leaves and cryptogam crusts suggesting the end of an arctic climate. The rare molluscs indicate severe climatic conditions during the deposit of the loess particles. The pockets of thin sand terminating the formation a little bit out of the sections (thermokarst) are no more carbonated. They are typically eolian and contain heavy minerals (mainly hornblend+epidote+garnet) identical to the heavy mineral sampled in the central part of the English Channel. This formation is affected by a small soil of hygromorph tundra. The main characteristic of this section is the clear existence of well expressed permafrost.

Since we know that the winds transporting the loess particles were coming from the North or the Northwest in Brittany (Bigot, 1986; Lefort et al., 2013b), the initial purpose of this study was to compare the various characteristics of the two loess which constitute the Nantois cliff and to check if their respective evolutions were controlled by a different distance between Nantois and the maximum extension of the Saalian and Weichselian British ice sheets (Ehlers et al., 2011, Figure 12). After our study it is unlikely that the differences observed in the grain size, mollusc faunas and climatic environments were related with the small difference in latitude of the boundaries of these icesheets. This limited difference in latitude cannot explain why a well expressed permafrost (Loyer et al., 1995) developed in the Weichselian and a very poorly expressed equivalent in the Saalian.

Comparisons between two equivalent loess have been already made in the Paris Basin (Locht et al., 2003; Limondin-Lozouet and Gauthier, 2003). The dry and sever climatic condition they observed in the Saalian and the variable but partly warmer conditions they found during the Weichselien differ from our observations. This maybe due to local conditions but also to the fact that we were not able to study the continuous malacologic evolution of the deposits in some parts of the Nantois sections because they were completely decalcified.

It is not sure that the results of the QUEEN Project (Colleoni, 2009) which suggest that the Eurasian ice-sheet was substantially larger during the Late Saalian period (160$130 \mathrm{ka}$ ) than during the entire Weichselian cycle (and especially during the Last Glacial Maximum around 25-21 Ka) can be applied to Nantois region. At a small scale, the discrepancy in the evolution of these two ice-sheets has been correlated with the fact that the Late Saalian ice sheet was extending more to the South and was consequently more sensitive to the successive ice ablations. On the contrary, the LGM Eurasian ice-sheet had a limited southward extent and was consequently less sensitive to the changes occurring over Central Eurasia (Colleoni, 2009). However, if we take account of the distances of these two fronts respect with the studied area it is doubtful that the differences observed between the Late Weichselian and the Saalian of Nantois were directly controlled by the general behavior of these two ice sheets.

The main difference which characterizes the old and the new loess of the Nantois cliff is the presence of three warming episodes during the Upper Saalian and the existence of a well expressed permafrost during the Weichselian. 


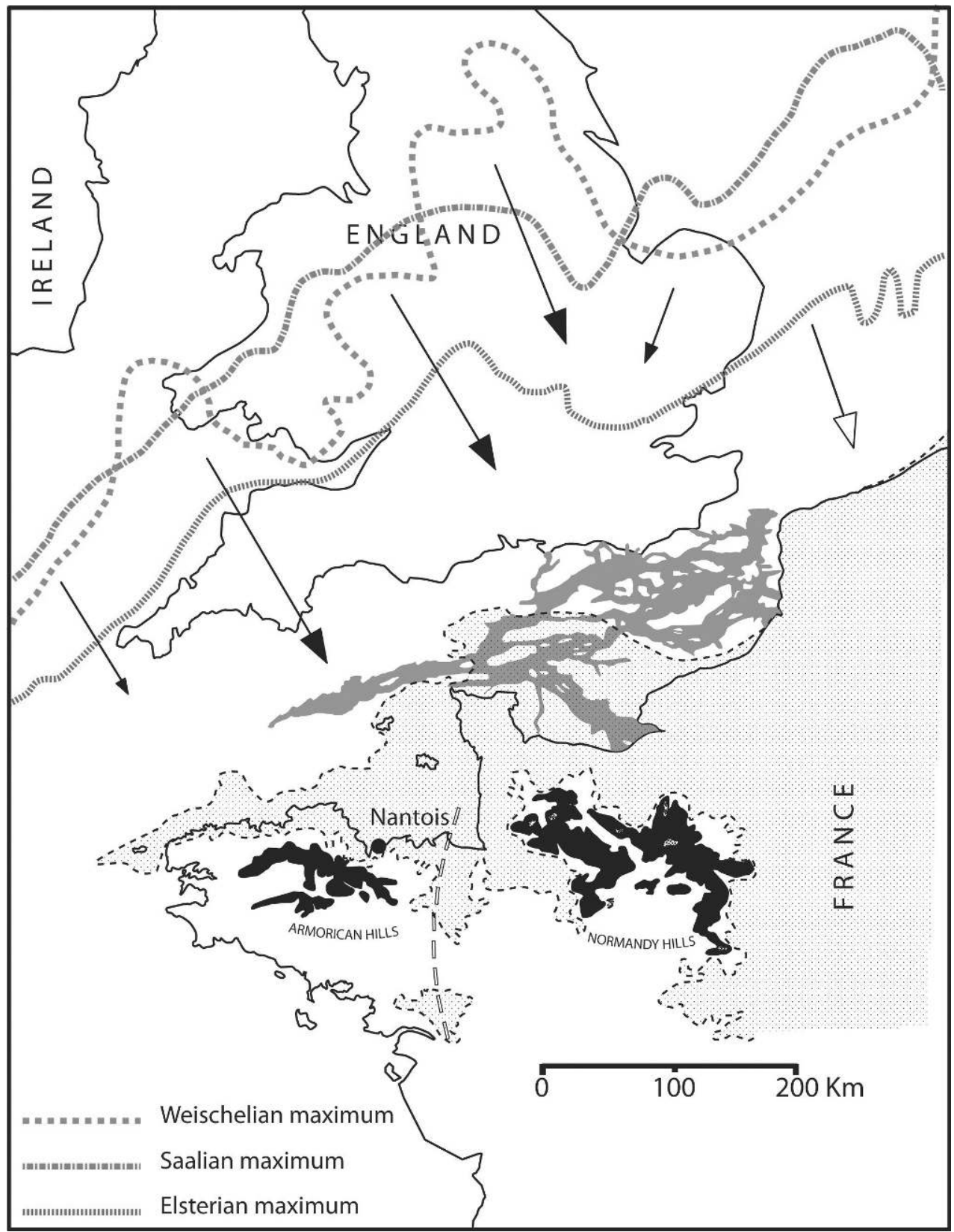

Figure 12: Regional map showing the location of the Nantois site respect with the southern limit of the Saalian and Weichselian British ice sheets. The arrows show the wind direction. Black: main reliefs known in Brittany and Normandy; grey: submerged braided rivers of the English Channel; stipples: loess deposits (partly after Ehlers et al., 2011). Figure 12 : Carte régionale montrant la localisation du site de Nantois par rapport aux limites saaliennes et weichseliennes de la calotte glaciaire britannique.

This apparent discrepancy is in fact artificial since the time spanning during the Upper Saalian and Upper Weischelian loess deposition is very different. Upper Saalian loess deposited during about $60 \mathrm{Ka}$ while the Upper Weischelian loess deposited only during $7 \mathrm{ka}$. If we accept the concept of sub-Milankovitch cycles observed or calculated by different authors (Berger, 1977; Gupta, 2009) showing that we cannot have any climatic change during a period shorter than $11 \mathrm{Ka}$, we better understand why no warming evidences can be found during the studied Upper Weischelian. Comparison between the maximum shell production during the Upper Weischelian (13 individuals/2,5 kg of sediment, figure 7 ) and the maximum shell production during the Upper Saalian (150 individuals/ for $2,5 \mathrm{~kg}$ of sediment, figure 6) support this interpretation.

\section{Acknowledgements}

The authors would like to thank the librarian Catherine Le Gall (Laboratory of Archéosciences, Rennes 1 University) for finding unusual and rare documents and Benoit Le Forban student in Master at Rennes 1 University for his help 
during the photos sessions at microscope. The authors would like to thank also the Administration of the Golf Blue Green of Pléneuf-Val-André for their help during sampling, Mrs. Natalya Bogatyreva (Geological Institute of the Ufimian scientific centre, RAS) for her help in collections labeling and Dr Larisa Belan for her help during correction of the manuscript. The authors would like also to express their thanks to D. Marguerie, P.-Y. Laffont and G. Marchand successively Directors and second Director of the UMR 6566 and of the Laboratory of Archéosciences (University of Rennes 1, France) to welcome J.-P. Lefort and G.A. Danukalova in their Laboratory. This work was partly achieved thanks to the Russian Government Program of Competitive Growth of Kazan Federal University. At last, the authors thank the reviewers of this paper for their comments and corrections and are very thankful to the Editorial Board for their help in improving and editing the original text.

\section{Bibliography}

Adam W., 1960. Faune de Belgique: Mollusques, 1. Mollusque Terrestres et Dulcicoles. Institut Royal des Sciences Naturelles de Belgique, $402 \mathrm{p}$.

Animal Base, n.d. http://www.animalbase.uni-goettingen.de.

Antoine P., 1990. Chronostratigraphie et environnement $d u$ Paléolithique du Bassin de la Somme. Publication du Centre d'Étude et de Recherches préhistoriques de Lille (CERP), 2, $231 \mathrm{p}$.

Antoine P., 1994. The Somme Valley terrace system (Northern France); a model of river response to quaternary climatic variations since 800000 BP. Terra-Nova 6, 453-464.

Antoine P., Lautridou J.-P., Somme J., Auguste P., Auffret J.-P., Baize S., Clet-Pellerin M., Coutard J.-P., Dewolf Y., Dugué O., Joly F., Laignel B., Laurent M., Lavollé M., Lebret P., Lecolle F., Lefebvre, D., Limondin-Lozouet N., Munauta, V., Ozouf J.C., Quesnel F., Rousseau D.-D., 1998. Le Quaternaire de la France du Nord-Ouest: limites et corrélations. Quaternaire 9 (3), 227-241.

Antoine P., Lautridou J.-P., Laurent M., 2000. Long-term fluvial archives in NW France: response of the Seine and Somme rivers to tectonic movements, climatic variations and sea level changes. Geomorphology 33, 183-207.

Antoine P., Catt J., Lautridou J.-P., Sommé J., 2003. The loess and coversands of northern France and southern England. Journal of Quaternary Science 18 (3-4), 309-318.

Bahain J.-J., Falguères C., Laurent M., Shao Q., Dolo J.M., Garcia T., Douville E., Frank N., Monnier J.-L., Hallégouët B., Laforge M., Huet B., Liouville M., Serre F., Gagnepain J., 2012. ESR and ESR/U-series dating study of several middle Palaeolithic sites of Pléneuf-Val-André (Brittany, France); Piégu, Les Vallées and Nantois. Quaternary Geochronology 10, 424-429.

BAlescu S., 1988. Apports de la thermoluminescence à la stratigraphie et à la sédimentologie des loess du Nord-Ouest de l'Europe. Thèse Doctorat eu Sciences, Université de Bruxelles, vol. I. 199 p.; vol. II. annexes, 144 p.

Bateman M., 1998. Geochronology. In The Quaternary of Kent and Sussex Field Guide, Murton JB, Whiteman CA, Bates MR, Bridgland DR, Long AJ, Roberts MB, Waller MP (eds). London, Quaternary Research Association, 30.

Beigbeder Y., 1964. Contribution a l'étude geomorphologique et sedimentologique de la partie orientale de la Baie de Saint-Brieuc. Thesis, Laboratoire de Géomorphology. Paris/Dinard, Ecole pratique des hautes études, $342 \mathrm{p}$.

Berger A. L., 1977. Support for the astronomical theory of climatic change. Nature, 269, 44-45.

Bigot B., 1986. Essai de modélisation de l'apport loessique en Bretagne (France). Comptes rendus de l'Académie des Sciences, Paris, 303 (II, 10), 919-921.

Busschers F.S., van Balen R.T., Cohen K.M., Kasse C., Weerts H.J.T., Wallinga J., Bunnik F.P.M., 2008. Response of the Rhine-Meuse fluvial system to Saalian ice-sheet dynamics. Boreas 37, 377-398.

Colleoni F., 2009. On the Late Saalian glaciation (160-140 ka) - a climate modeling study. Department of Geology and Geochemistry. Stockholm, US-AB SU, Sweden, 1-53.

DANILOVSKYI I.V., 1955. Scandinavian glaciation deposits key site of the Russian Plain and Quaternary molluscs. Moscow, Gosgeoltekh Press, (Transactions of the VSEGEI, V. 9) (in Russian).

Danukalova G., Lefort J.-P., Osipova E., Monnier J.-L., 2013. Recent advances in the stratigraphy of the Upper Pleistocene of Westernmost Europe: La Haute Ville and Bréhat Cliffs (Northern Brittany, France). Quaternary International 284, 30-44.

Ehlers J., Gibbard Ph.L., Hughes Ph.H., 2011. Quaternary glaciations: extent and chronology. Elsevier, $1108 \mathrm{p}$.

Estéoule J., Estéoule-Choux J., Perret P., 1971. Constitution minéralogique et origine des limons de la côte Nord-Est de Bretagne. Comptes Rendus de l'Académie des Sciences. Paris, 273 D, 1355-1358.

Excursion GuIde Book, 2008. Differences and similarities in Quaternary stratigraphy between Atlantic and continental Europe. INQUA-SEQS Meeting, 22-27 September 2008, Rennes, France. J.-L. Monnier, J.-P. Lefort, G. Danukalova (Eds), Travaux du Laboratoire d'anthropologie de Rennes N 45, 68 p.

Falkner G., Ripken T.E.J., Falkner M., 2002. Mollusques continentaux de France. Liste de Références annotées et Bibliographie. Patrimoines naturels 52, 1-350. Publication du Muséum National d'Histoire Naturelle (Paris). France. 
Germain L., 1930. Faune de France. Mollusques terrestres et fluviatiles. t. 21 et 22. Lechevalier pub., Paris, 893 p.

Gibbard P.L., Cohen K.M., 2008. Global chronostratigraphical correlation table for the last 2.7 million years. Episodes 31 (2), 243-247.

Google MAPs, n.d. www.maps.google.com

Gupta S.M., 2009. Radiolarian abundance - A monsoon proxy responding to the Earth's orbital forcing: Inferences on the mid-Brunhes climate shift. Earth Science India, Vol.2 (I); 1-20.

Haesaerts P., Dupuis C., 1986. Contribution à la stratigraphie des nappes alluviales de la Somme et de l'Avre dans la région d'Amiens. In: Chronostratigraphie et faciès culturels du Paléolithique inférieur et moyen dans l'Europe du NordOuest, vol. 26. Supplément Bulletin de l'Association Française pour l'Étude du Quaternaire, p. 171-186.

Keen D., 1982. Late Pleistocene Land Mollusca in the Channel Islands. Journal of Conchology 31, 57-61.

Keen D., 1986a. Late Pleistocene land Mollusca from Portelet, Jersey. Journal of Conchology 32, 200.

Keen D., 1986b. The Quaternary deposits in the Channel Islands. In P. Callow, J.M. Cornford (eds.), La Cotte de St. Brelade, Jersey - Excavations by C.B.M. McBurney 1962-1980. Geobooks, Norwich, p. 43-54. Chapter 5.

Keen D., Lauriat-Rage A., Van Vliet-Lanoë B., Hallégouet B., 1997. The calcareous shore face of St Brieuc Bay. The Quaternary of Brittany. Guide Book. Revue archéologique de l'Ouest, 56-58.

Kerney M.P., Cameron R.A., Jungbluth J.H., 1983. The land snails of North and Middle Europe. Hamburg, p. 186-189.

Kerney M.P., Cameron R.A.D., 1999. Guide des Escargots et limaces d'Europe. Lausanne, Delachaux et Niestle S.A., 370 p.

LAFORGE M., 2012. Le cadre chronostratigraphique des peuplements pléistocènes de l'Ouest de la France. Eustatisme, changements climatiques et occupations humaines. Ph. D. Thesis, University of Rennes 1, 263 p.

Lautridou J.-P., 1971. Conclusions générales des recherches de gélifraction expérimentale. Centre National des Recherches Scientifique, Centre de Geomorphologie de Caen, Bulletin 10, 43-61.

Lautridou J.-P., 1985. Le cycle périglaciaire pléistocène en Europe du Nord-Ouest et plus particulièrement en Normandie. Caen, Centre Géormophologie (ed.), 908 p.

Lautridou J.-P., Puissegur J.-J., 1977. Données nouvelles sur les microfaune malacologiques et sur les rongeurs du Pléistocène continental de la Basse-Seine. Bulletin de la Societé géologique de Normandie 64, 119-127.

Lebret P., Lautridou J.-P., 1991. The loess of West Europe. Geo Journal 24(2), 151-186.

Lefort J.-P., Danukalova G.A., Monnier J.-L., 2011. Origin and emplacement of the loess deposited in Northern Brittany and under the English Channel. Quaternary International 240, 117-127.

Lefort J.-P., Danukalova G., Monnier J.-L., 2013a. Why the submerged sealed beaches, last remnants of the low stands of the Upper Pleistocene regression, are better expressed in the Western than in the Eastern English Channel? Geo-Eco-Marine 19, 1-16.

Lefort J.-P., Monnier J.-L., Danukalova G., 2013b. Deflation and transportation of the Upper Pleistocene Loess particles by katabatic winds during the lowstands of the English Channel: New data and new constrains. Contribution of the heavy minerals. SEQS/INQUA Meeting, Constantsa, Romania, National Institute of Marine Geology and Geoecology, Bucharest, 25-26.

Lericollais G., 2007. Quand la Manche était un fleuve. Pour La Science, 356, 62-68.

Likharev I.M., Rammelmeier E.S., 1952. Land molluscs of the fauna of the USSR. Leningrad/Moscow, Academy of Sciences of USSR Press, 512 p. (Determinative tables of the USSR fauna. Proceedings of the Zoological Institute of the USSR Academy of Sciences 43 (in Russian).

Limondin-Lozouet N., Gauthier A. 2003. Biocénoses Pléistocènes des séquences loessiques de Villier-Adam (Vald'Oise, France); Études Malacologiques et palynologiques. Quaternaire, 14 (4), 237-252.

Locht J.-L., Antoine P., Bahain J.-J. et al., 2003 Le gisement Paléolithique Moyen et les séquences Pléistocènes de VilliersAdam (Val-d'Oise) : chronostratigraphie, environnement et implantations humaines. Gallia Préhistoire, 45, 1-111.

Loyer S., Monnier J.-L., van Vliet-Lanoë B., Hallégouët B., Mercier N., 1995. La coupe de Nantois (Baie de SaintBrieuc, France) : datations par thermoluminescence (TL) et données paléoenvironnementales nouvelles pour le Pléistocène de Bretagne. Quaternaire 6 (1), 21-33.

Ložek V., 1964. Quartärmollusken der Tschechoslowakei. Rozpravy Ustredniho ustuvu geologického 31, 1-374.

Madgett P.A, Catt J.A., 1978. Petrography, stratigraphy and weathering of Late Pleistocene tills in east Yorkshire, Lincolnshire and north Norfolk. Proceedings of the Yorkshire Geological Society 42, 55-108.

Mazeres R., 1938. Contribution à l'étude des formations quaternaires des Côtes-du-Nord. Bulletin de la Societé Géologique et Minéralogique de Bretagne, 13-16.

Moine O., 2008. West-European malacofauna from loess deposits of the Weichselian Upper Pleniglacial: compilation and preliminary analysis of the database. Quaternaire 19 (1), 11-29.

Monnier J.-L., 1973. Contribution a l'étude des dépôts quaternaires de la région de Saint-Brieuc. Travaux du Laboratoire d'Anthropologie - Préhistoire - Protohistoire - Quaternaire - Armoricains. Thèse $3^{\mathrm{e}}$ cycle, University of Rennes 1, 259 p. 
Monnier J.-L., 1974. Les depôts Pléistocènes de la region de Saint-Brieuc - stratigraphie et préhistoire. Bulletin de la Societé géologique et minéralogique de Bretagne 6, 43-62.

Monnier J.-L., 1980. Le Paléolithique de la Bretagne dans son cadre géologique. Ph. D thesis. Univ. Rennes, France.

Monnier J.-L., 1986. Le gisement paléolithique moyen de Nantois, Pléneuf (Côtes-du-Nord). Bulletin de la Société préhistorique française 83, 146-150.

Monnier J.-L., Bigot B., 1987. Stratigraphie des dépôts pléistocènes du nord de la Bretagne (France), les Formations de PortMorvan et de la Haute-Ville. Bulletin de l'Association française pour l'Étude du Quaternaire 32 (2), 93-103.

Monnier J.-L., van Vliet-Lanoë B., Hallégouët B., Frechen M., 1997. Loesses. In The Quaternary of Brittany. Guide book of the excursion in Brittany, 12-15 September 1997. Organisators: B. van Vliet-Lanoë, B. Hallégouët, J.-L. Monnier. Travaux du Laboratoire d'Anthropologie, Université de Rennes 1. Special issue, 24-28.

Monnier J.-L., Huet B., Laforge M., 2011. Application of sedimentological analysis to correlation of eroded layers under beaches with local and regional Pleistocene stratigraphy: A contribution to geological dating of Palaeolithic sites, northern coast of Brittany, France. Quaternary International 231 (1-2), 78-94.

Osipova E., Danukalova G., Marković S., 2013. Malacological characteristic of the Middle Pleistocene loess (MIS 6) of the Batajnica locality (Serbia). Quaternary International 292, 86-100.

Parks D.A, Rendell H.M., 1992. Thermoluminescence dating and geochemistry of loessic deposits in southeast England. Journal of Quaternary Science 7, 99-107.

PuissÉgur J.-J., 1976. Mollusques continentaux quaternaires de Bourgogne. Significations stratigraphiques et climatiques. Rapports avec d'autres faunes boréales de France. Mémoires géologiques de l'université de Dijon 3, 241 p.

Shileyko A.A., 1978. Land molluscs of the Helicoidea. Nauka Press, Leningrad, 384 p. (Fauna of the USSR) Mollusca 3 (6) (in Russian).

Shileyкo A.A., 1984. Land molluscs of the Pupillina (Gastropoda, Pulmonata, Geophila). Leningrad, Nauka Press, 399 p (Fauna of the USSR) Mollusca 3 (3) (in Russian).

Shileyko A.A., Likharev I.M., 1986. Land molluscs of the family Succineidae of the fauna of the USSR. In Archives of
Zoological Museum of Moscow State University XXIV, Fauna, Systematics and Phylogeny of the Invertebrated Animals, 198-238 (in Russian).

Sibrava V., Bowen D.Q., Richmond G.M., 1986. Quaternary glaciations in the Northern hemisphere. Quaternary Science Reviews 5, 510 p.

Sommé J., 1980. Nord de la France: géomorphologie, formations superficielles, Quaternaire. Paris, CERG (CNRS), Institut de géographie.

Steklov A.A., 1966. Neogene terrestrial molluscs of the ForeCaucasus and their strartigraphical significance. Moscow, Nauka Press, 262 p. (Proceedings of the Geological Institute RAS, 163) (in Russian).

Sysoev A., Shileyкo A., 2009. Land snails and slugs of Russia and adjacent countries. Sofia/Moscow, Pensoft publishers, $312 \mathrm{p}$.

SüMegi P., Krolopp E., 2002. Quartermalacological analyses for modeling of the Upper Weichselian palaeoenvironmental changes in the Carpathian Basin. Quaternary International 91, 53-63.

Turner Ch., 1998. Volcanic maars, long Quaternary sequences and the work of the INQUA subcommission on European Quaternary stratigraphy. Quaternary International 47/48, 41-49.

Willis K., Rudher E., Sümegi P., 2000. The Full-Glacial Forests of Central and Southeastern Europe. Quaternary Research 53, 203-213.

Wintle A.G., 1981. Thermoluminescence dating of Late Devensian loesses in southern England. Nature, London 289, 479-480.

White D., Preece R., Shchetnikov A., Parfitt S., Dlussky K., 2008. A Holocene molluscan succession from floodplain sediments of the upper Lena River (Lake Baikal region), Siberia. Quaternary Science Reviews 27, 962-987.

ZAGWIJN W.H., 1996. Borders and boundaries: a century of stratigraphical research in the Tegelen-Reuver area of Limburg (The Netherlands). Abstracts of the INQUA-SEQS Conference "The dawn of the Quaternary", 2-9.

Zilch A., Jaeckel S.G.A., 1962. Die Weichtiere (Mollusca) Mitteleuropas. Die Tierwelt Mitteleuropas. Bd. II, L. I. Leipzig, Verlag von Quelle \& Meyer, 294 p. 